\title{
SURVIVAL AND GROWTH IN RETAIL AND SERVICE INDUSTRIES: EVIDENCE FROM FRANCHISED CHAINS*
}

\author{
RenÁta Kosová ${ }^{\dagger}$ \\ FRANCINE LAFONTAINE
}

\begin{abstract}
Using data on franchised chains, which are the type of single-product entities emphasized in industry dynamics models, we show that age and size affect growth and survival even after controlling for chain characteristics and unobserved chain-specific efficiency. This implies that age and size affect firm growth and survival for reasons other than those emphasized in learning-type models. We also find that several chain characteristics affect growth and survival directly, and thus controlling for firm characteristics is important. Finally, we find that chain size increases rather than decreases exit among young chains, and chains converge in size over time.
\end{abstract}

\section{INTRODUCTION}

THE EMPIRICAL MICRO-LEVEL LITERATURE ON FIRM SURVIVAL AND GROWTH has flourished since Evans [1987a,b] and Dunne, Roberts and Samuelson's [1988, 1989] early work. This literature has established a number of stylized facts, including a tendency for large and older firms to grow less rapidly, but fail less frequently, than young and small firms (see, e.g., Klepper and Thompson, [2006] for a summary). These stylized facts, in turn, have stimulated the development of much more theoretical work on firm and industry dynamics. ${ }^{1}$

In this paper, we examine the growth and survival of franchised chains. We focus on these chains for several reasons, starting with the fact that the retail and service sectors are increasingly important parts of the economy in

\footnotetext{
*We thank the Editor, an anonymous referee, and Patrick Bajari, Andrew Bernard, Michael Gort, Boyan Jovanovic, Steven Klepper, Jagadeesh Sivadasan, Eric Van Den Steen, and participants at several conferences and seminars for their comments. We also thank Robert Picard for his assistance. The usual caveat applies.

†Authors' affiliations: School of Hotel Administration, Cornell University, 545B Statler Hall, Ithaca, New York 14853, U.S.A. e-mail:rk373@cornell.edu

${ }^{\ddagger}$ Ross School of Business, University of Michigan, 701 Tappan St., Ann Arbor, Michigan 48109, U.S.A.

e-mail:laf@umich.edu

${ }^{1}$ See notably Jovanovic [1982], Hopenhayn [1992], Ericson and Pakes [1995], as well as surveys by Sutton [1997] and Caves [1998]. Cabral and Mata [2003] provide a nice summary of stylized facts on firm size distributions. 
developed countries. According to the Bureau of Labor Statistics, as of December, 2008, about 13 million of the 112.5 million non-farm employees in the private sector in the U.S. worked in manufacturing, while 92 million workers were involved in private service industries, including 15 million in retailing and another 13.3 million in the leisure and hospitality sector. ${ }^{2}$ Moreover, most of the productivity growth in the U.S. since the mid 1990's has been traced back to improvements in the efficiency of the wholesale, retail, and service sectors (O'Mahony and Van Ark [2003]; Bloom et al. [2007]). Yet, with a few exceptions, the empirical literature on industry dynamics has been almost entirely about manufacturing firms. ${ }^{3}$ One goal and motivation of our paper is to examine whether the same stylized facts, and thus theories of firm and industry dynamics, are relevant also outside of manufacturing, or whether there is a need for further theoretical work directed specifically at the retail and small-scale service sectors.

But why focus on franchised chains as opposed to all retailing? First, chains are a growing phenomenon in the retail and small-scale service sectors (see, e.g., Basker and Pham [2007]), and franchising is an important way to organize such chains. ${ }^{4}$ In 2005 , according to PricewaterhouseCoopers [2008], franchised businesses accounted for 11 million jobs, or 8.1 per cent of all private non-farm jobs in the U.S. economy. ${ }^{5}$

Most importantly, however, our interest in franchised chains stems from the fact that models of firm/industry dynamics typically assume that firms each produce a single product. Manufacturing firms, whose data have been used to test the models, usually are involved in the production of a variety of products, some of which they abandon over time while introducing others

\footnotetext{
${ }^{2}$ See Bureau of Labor Statistics (http://www.bls.gov/data/) - Summary table B. Employment, hours, and earnings of employees on nonfarm payrolls, seasonally adjusted (ftp:// ftp.bls.gov/pub/suppl/empsit.cessum.txt).

${ }^{3}$ Exceptions include some studies of large-scale service providers, namely firms from the finance, insurance and real estate sectors (e.g., Troske [1996]). Also, Pakes and Ericson [1998] compare active versus passive learning models and suggest that manufacturing firms engage in active learning but that passive learning models such as Jovanovic's [1982] might better characterize retailing. Petrunia [2007] finds similar results using Canadian firm-level data. Finally, Audretsch et al. [2004] examine whether Gibrat's law holds for firms in small-scale service industries, Foster et al. [2006] analyze productivity growth in retailing and Jarmin et al. [2004] characterize industry dynamics in U.S. retailing empirically.

${ }^{4}$ Most of the literature on franchising has focused on issues of organization, namely the decision to franchise or not, and the terms of franchise contracts. See Blair and Lafontaine [2005] and Lafontaine and Slade (2007), for overviews of this literature. To our knowledge, there are no models of industry dynamics that are specific to franchising or, more generally, chains. However, see Lafontaine and Shaw [1999, 2005] on the relative stability of contracting practices within chains over time.

${ }^{5}$ Business-format franchising, where franchisors provide a 'way of doing business' in exchange for royalties on sales typically, accounts for 9 of these 11 million jobs., with the other type, traditional franchising, providing the remainder. Our data are about business-format franchises only.
} 
(Bernard, Redding and Schott [2006, 2010]). ${ }^{6}$ It is therefore not obvious how a manufacturer's age relates to its experience at producing a particular product, nor how its total size relates to its sales of a particular product at a point in time. In fact, manufacturing firms, like many retail firms, continuously modify their product mix in order to continue to grow and avoid failure. This possibility is absent from most theoretical models. ${ }^{7}$

Franchised chains, on the other hand, are fundamentally 'single-product' entities as the set of products offered is relatively constant over time, and chosen centrally by the franchisor. ${ }^{8}$ In fact, the value of a franchise depends on a strong association between the brand and the set of products and services [or product mix] that customers expect to find at each outlet. ${ }^{9}$ While they make small adjustments over time, franchised chains rarely make fundamental changes to their product offerings, and the issue of consistency or uniformity across outlets is paramount to these chains. ${ }^{10}$ Further, with franchisee ownership of individual outlets, substantial change is especially difficult to implement in franchised chains compared to corporate chains such as Starbucks, for example. ${ }^{11}$ Thus, for franchised chains, either the concept developed early on and associated with the brand remains successful in the market, and the chain grows via cloning of the concept in different locations, or it does not, and the chain stops growing, or even exits.

We rely on the strong association between brand and products in franchised chains to argue that a chain's age and size capture exactly the type of product-specific learning emphasized by most of the theories. As a result, our data on franchised chains allow us to provide better tests of the predictions from the single-product models of firm dynamics than the empirical literature has produced so far.

Our panel data set on franchised chains offers several other advantages relative to manufacturing data sets used in the literature. First, we know several things about each franchised chain in our data besides its age and size. Hence, we can examine how the introduction of other observed 'firm' or chain characteristics, as well as chain unobserved heterogeneity, modifies

\footnotetext{
${ }^{6}$ See also Gort [1962] for earlier evidence on this topic.

${ }^{7}$ Recently, Mitchell [2000], Klepper and Thompson [2006], Bernard et al. [2006, 2010] and Nocke and Yeaple [2006] have proposed models of firm dynamics where firms engage in more than one activity.

${ }^{8}$ We use the words 'product' or 'business format' or 'concept' interchangeably to mean the menu of product options offered at each outlet in a chain.

${ }^{9}$ Some large franchise companies offer a variety of 'product' options through the different franchise chains that they own and operate. This is the case for example for Choice Hotels International, which owns Comfort Inn, MainStay Suites, Econo Lodge and several other chains, and for Yum! Brands Inc., the largest fast-food restaurant company in the world, which owns brands such as KFC, Pizza Hut, Taco Bell and several others and finally, Service Brands International, owner of Molly Maid and Mr. Handyman, among others.

${ }^{10}$ See, e.g., Blair and Lafontaine [2005], chapter 5, and Bradach [1998] on the importance of uniformity.

${ }^{11}$ For an excellent case study reflecting this reality, see Kaufmann [1987].
} 
results pertaining to the impact of chain age and size. These analyses are important because in a Jovanovic [1982] learning-type model, firm age and size affect survival rates and growth exactly because they capture the intrinsic 'efficiency' of the firm. Evans [1987a, b], however, suggests that theories of firm growth should be expanded to consider how other factors besides age and size might play a role. In addition, Klepper and Thompson [2006] note that the significant effects of age and size on growth and exit in the empirical literature may arise because of other factors correlated with these variables that are omitted from the empirical models. Consistent with these arguments, in their seminal work, Dunne, Roberts and Samuelson [1989] included ownership type, industry and year effects, as well as the effect of initial plant size in their empirical model of plant survival and growth. They found that ownership type had a large effect on the relationship between size and growth. By 2003, however, Geroski et al. still pointed to the lack of firm fixed effects and other firm characteristics as a major deficiency of the current empirical literature on firm and industry dynamics. Thus, besides providing more relevant tests of the theoretical predictions, a second important question we can answer is whether age and size still matter once we include other firm characteristics in the empirical model, and control for efficiency or chain unobserved heterogeneity directly.

Lastly, our data set on franchised chains represents a much longer panel than is typical in the empirical firm dynamics literature. This means that we can analyze a third main question in this literature, namely whether age and size effects differ for mature chains, as predicted by learning-based theories.

We find first that, even after controlling for chain unobserved correlated heterogeneity (or chain fixed effects) and various chain characteristics, the impact of age and size on chain growth, and the impact of age on chain survival, are consistent with findings in prior studies. This is despite the fact that such studies focused mostly on manufacturing firms/establishments, and did not control for firm unobserved heterogeneity. Our results imply that the unknown production efficiency of a firm, and the subsequent learning process posited by Jovanovic-like learning models, are not the only, nor perhaps the main, reason for the empirical relationships found between firm age and size on the one hand, and firm exit and growth on the other hand. Moreover, since these age and size effects are robust to the introduction of contract variables and other controls, we can conclude that these chain characteristics are not driving the age and size effects either.

Second, we find that controlling for chain unobserved correlated heterogeneity is crucial as it reverses the impact of size on chain survival. The finding that larger size increases the likelihood of failure 'within' chains - while the opposite is true cross-sectionally in our data as well as in previous studies - is intriguing as it is inconsistent with the implications of most theoretical models. When we focus on mature chains, however, neither chain age nor size has a statistically significant effect on exit rates. Thus the positive 
effect of chain size on exit within chains is a young firm effect. We believe this result is best explained by a tendency of young chains to be too aggressive early on and make 'mistakes' - or over-optimistic assessments about their odds of success in the market. ${ }^{12}$ In that sense, our findings relate to the large literature on overconfidence in finance and entrepreneurship. Moreover, organizational features of franchised chains likely contribute further to this tendency for mistakes and overconfidence as franchisees [not the franchisor] bear most of the cost of outlet failures.

Finally, our analyses of mature chains show that chain age affects growth negatively in all but the oldest subset of chains [greater than 30 years in franchising] and chain size has a significant, though small, negative effect on growth rates in all subsets. Together with the findings above, these results imply that franchised chains converge in size to chain-specific levels, a tendency that has not been so apparent in studies of manufacturing firms. In other words, when we focus on single-product entities, there is a limit to size as predicted by Jovanovic [1982] and many other models of firm dynamics. This limit, not surprisingly, is product or 'concept' specific, reflecting, in our view, the differences in demand for the product concepts of the chains.

The paper is organized as follows. In the next section, we briefly review related literature and provide a framework for our empirical analyses. In Section III we describe our data on franchised chains and address several issues that arise in measuring growth and exit in this context. In Section IV, we present our empirical model and results. Section V concludes.

\section{FRANCHISING AND INDUSTRY DYNAMICS}

The early literature on firm growth emphasized the predictions of Gibrat's law, which implicitly focused on the growth of surviving firms. ${ }^{13}$ Many models of industry dynamics have been proposed since as authors have tried to explain the stylized facts arising from empirical analyses of entry, exit and growth at the firm or establishment level. Jovanovic [1982] developed a model based on self-selection, where firms are endowed at birth with an unknown efficiency parameter that they learn about as they operate in perfectly competitive industries. Relying largely on this framework, Dunne, Roberts and Samuelson [1988, 1989] argued that the hazard of firm exit should be decreasing in firm age and size. ${ }^{14}$ As for firm growth, predictions were less clear: for non-failing firms, holding age (size) fixed, the mean

\footnotetext{
${ }^{12}$ We thank an anonymous referee for highlighting this result.

${ }^{13}$ Gibrat's law amounts to an assumption that firm growth in each period is proportional to its current size. This, in turn, implies that the firm growth rate is random and the size distribution of firms is lognormal in the limit. See, e.g., Sutton [1997], Cabral and Mata [2003], Geroski et al. [2003], Audretsch et al. [2004] or Petrunia [2008].

${ }^{14}$ However see Pakes and Ericson [1998] for an example of functional form that results in an exit hazard function that is initially increasing in age.
} 
growth rate should at some point decrease with size (age). For all firms, then, the net effect of age and size on growth would depend on the importance of the reduction in failure rate compared to the reduction in the growth rate of non-failing firms. Evans [1987a], however, argued that the effect of firm age on growth should be negative in Jovanovic's model if output were convex in managerial inefficiency. ${ }^{15}$

Jovanovic's [1982] model has been extended in several ways. Jovanovic and Rob [1987] in particular consider the effect of firm size on survival and growth when single-product firms compete in differentiated rather than homogeneous product markets. They assumed that in the course of doing business, firms gather information from their customers which they can use to improve their product. The larger a firm is, the more information it obtains, and the better it can tailor its product to the market. Thus success feeds on itself, so that firm size should be positively correlated over time, and could be unbounded if the firm successfully improved its product over time.

Recent models by Sutton [1997, 1998], Mitchell [2000], Klepper and Thompson [2006], Bernard, Redding and Schott [2006, 2010], and Nocke and Yeaple [2006] specifically allow firms to engage simultaneously in more than one activity. ${ }^{16}$ Because of limited factors of production such as managerial talent (Bernard et al.) or organizational capability (Nocke and Yeaple), or because of lack of information and resulting communication problems (Mitchell) or the finite duration of submarkets (Klepper and

\footnotetext{
${ }^{15}$ In the empirical literature, firm age and size enter the specifications for firm growth and survival because they reflect some type of firm learning process and/or firm type. Cooley and Quadrini [2001] point out, however, that the basic Jovanovic type of learning model cannot generate the kind of simultaneous dependence on both size and age that has been found in the empirical literature (e.g., Evans [1987a, b] and Hall [1987]). Similarly in Hopenhayn's [1992] model, size is a sufficient statistic for firm type and thus age has no extra predictive role. To generate the implication that firm size has a negative impact on a firm's growth rate when one controls for firm age, and vice versa, Cooley and Quadrini [2001] rely on a model that combines persistent shocks to firm productivity, as in Jovanovic [1982], with financial market frictions. The drawback of their model, however, as Klepper and Thompson [2006] point out, is that it does not generate any prediction as to the effect of firm age on the probability of exit. Clementi and Hopenhayn [2006], however, develop a model with endogenous financing constraints whose implications are consistent with all the stylized facts on the impact of age/size on firm growth and survival. The authors point out that the main advantage of their model compared, for example, to Jovanovic [1982] or Hopenhayn [1992] is not that it yields new implications, but that it is technically simpler and gives a role to capital structure.

${ }^{16}$ Klepper and Thompson [2006] elaborate on Sutton's [1998] idea where firm growth opportunities arise from the creation of new submarkets. Though this notion of submarket may be appealing as a way to think of the operations of a franchise chain across geographic markets, the specific characteristics the authors ascribe to their submarkets do not apply to our setting. First, their submarkets come into existence and then ultimately disappear. Though this may describe well new markets arising from new technologies, per the theory of product life cycle, it does not fit the notion of geographic regions as these usually do not disappear. Second, in their model, the more submarkets a firm participates in, the greater the scope or diversity of product offerings. As we have already explained, in our data increased geographical distribution does not represent greater product diversity, but rather increased scale. In their model, scale remains constant during each submarket's lifetime.
} 
Thompson), these models all imply limits to firm scope. But while the Klepper and Thompson and the Nocke and Yeaple models also imply limits to 'overall' firm size, other models are less conclusive on this issue. By contrast, the models that focus on single-product entities - like the franchise chains whose data we rely on - usually imply that these should face such a limit. This occurs because the 'firm's' efficiency level determines its optimal scale of production. As noted by Bernard et al. [2006], 'Further research is needed into the respective roles of firms' intensive (how much of each product is produced) and extensive (how many products are produced) margins in firm growth' (p. 23). Our chain-level analyses represent the first attempt at exploring the factors that affect the intensive margin (or scale) of firm growth.

To our knowledge, there are no models of industry dynamics that are specific to franchising or chains. Pakes and Ericson [1998] contrast Jovanovic's passive learning model and its implications with those derived from Ericson and Pakes' [1995] model where firms engage in active research and exploration. Using data on Wisconsin firms, the authors find that passive learning better describes retailing firms while active learning seems to better characterize manufacturing firms. They reach this conclusion because the firm size distribution changes much less, and gets closer to the crosssectional size distribution much faster, in retail than in manufacturing. In line with arguments that we present below, one justification for their finding is that retailers typically face a more local demand, and hence a more binding constraint on their size, than manufacturers do. Foster, Haltiwanger and Krizan [2006] similarly point to the importance of location and ownership structure as potential sources of differences between retailing and manufacturing, suggesting that firm age and size may not affect survival and growth in the same way in both sectors of the economy. And indeed growth over time via the addition of outlets in different markets, as occurs in the type of retail and service chains we focus on, may not generate the same 'learning' as would growth over time within a plant or a manufacturing firm. In particular, adding more outlets typically means signing new contracts with existing or new franchisees, and growing the chain geographically in ways that might exacerbate agency problems within the chain and thus reduce the chain's efficiency. As a result, chain age (and size) may not have the same effect on survival or growth in our data as for manufacturing firms. We explore these issues below, after describing our data in the next section.

\section{DATA AND MEASUREMENT}

Our 1980-2001 chain-level data come from two main sources: From 1980 to 1992 inclusively, we rely on the Entrepreneur magazine's ‘Annual Franchise 500' surveys. Starting with the 1993 data, we use the Source Book of Franchise Opportunities, now called Bond's Franchise Guide, as this source 
gives more detailed information on each franchised chain. Both of these sources provide information for about 1,000 franchised chains each year. ${ }^{17}$ But while the number of chains is rather stable from year to year in the sources, the dataset itself is quite unbalanced. Specifically, our data set contains 22,216 yearly observations for 5,044 different franchised chains, i.e., about four observations per chain on average (see the data appendix for more information on how we arrived at this sample and its composition). The population of franchisors in the U.S., in contrast, has been estimated at about 2,500 franchisors throughout the same period. The much larger number of franchisors in our data is due mostly to entry and exit. Indeed, we see more than 200 new chains starting to franchise each year throughout the 1980 's. Of these, only about 40 per cent continue franchising after ten years, and only $30-35$ percent after 15 years. ${ }^{18}$ Our panel is unbalanced, however, also due to missing data for 1999 , a year when our data source was not published, and because we have been fairly conservative in matching chains across years. Specifically, if we could not find a reliable match in terms of name and address, we assumed the data were for a different chain. Finally, random non-responses, or the fact that some chains that answered the survey one year may not have responded the next year, also contribute to the unbalanced nature of our data.

For each franchisor, our data include information on: 1) the number of company-owned and franchised outlets each year, 2) the year when a franchisor started the business and the year it started franchising, 3) royalty rates, advertising rates, franchise fees and ongoing fixed payments, and 4) franchisor's characteristics including the amount of capital required to open an outlet, the state (or country if Canada) where it is headquartered, and the type of business it is involved in.

The fact that most franchised chains develop their franchise programs after experimenting with one or a few corporate outlet(s) for a certain amount of time, and that franchisors usually operate some of their outlets corporately even once they become established franchised companies, affects how one may measure chain 'age' and 'size' and define its growth and survival. ${ }^{19}$ We describe how we measure each of these, and all other variables, in the remainder of this section.

\section{III(i). Measuring Exit and Growth}

We determine the chain exit year by finding the last year in which the chain is listed in either of our main sources, or in a third franchise directory, the

\footnotetext{
${ }^{17}$ The data for a given year are from the following year's edition as both sources are published early in the year.

${ }^{18}$ The average duration for chains with complete spells in our data is eight years. See Blair and Lafontaine [2005], Chapter 2, for more discussion.

${ }^{19}$ See Lafontaine and Shaw [2005] and Blair and Lafontaine [2005] for more on this. 
Franchise Annual. ${ }^{20}$ When a chain is no longer found in any of these, it is deemed to have exited franchising the year after it last appeared in any of them. ${ }^{21}$ Once we identify the year of exit, we allow a 2 -year prior to exit window to incorporate the delays in reporting and mismatch between the true time of exit from franchising and what we considered the time of exit for data matching purposes. ${ }^{22}$

Some exits in our data may reflect cases where chains are bought by other franchisors that then consolidate all their holdings in a single chain. Fortunately, chains that are purchased most often continue to be developed and listed separately in the directory. Of course these should not, and will not, appear as exits in our data. If the buyer instead decides to discontinue the use of the purchased brand and consolidate the outlets with those of their existing chains, or just discontinue them, the buyouts should be, and are, counted as exits in our data. ${ }^{23}$

Given our methodology to identify exits, an exit may mean that the chain has ceased to franchise, or ceased to exist altogether. According to the USDOC [1988: 12-13), among chains that exit franchising, roughly half choose to stop franchising. In other words, the firm decides that franchising is not right for them. These chains then typically either close down or 'buy back' franchised outlets, and continue to operate from that point on as wholly-owned (i.e., vertically integrated) chains. ${ }^{24}$ The other half of the chains that stop franchising, according to the USDOC, cease all operations so no outlets remain in business.

Based on this information, we expect that about half of the exits in our data will be cases where all operations cease (failure) while the other half would represent cases where firms decided that franchising was not right for them. Note that according to Trutko et al. [1993], initial franchise development costs for franchisors can exceed $\$ 500,000 .{ }^{25}$ This amount includes expenses incurred to develop clear and complete operating manuals, contracts, disclosure documents and so on, as well as franchise

\footnotetext{
${ }^{20} \mathrm{We}$ relied also on various internet sites, including individual franchisor and franchisee sites, to resolve ambiguous cases, especially towards the end of our sample period.

${ }^{21}$ See Shane [1996] and Lafontaine and Shaw [1998, 1999] who also used this approach.

${ }^{22}$ Specifically, if the year of exit from franchising for chain A was 1999, but the last year its data were available was 1997, we assumed that the chain exited franchising in 1997 and ascribed the 1997 data to its exit year.

${ }^{23}$ Shane [1996] contacted the founders of the 138 chains in his sample and verified that none had been acquired or had changed names, confirming that such events are quite rare.

${ }^{24}$ To our knowledge, only two studies have examined why chains that continue to operate choose to stop franchising. These studies were based on fairly small samples, one conducted in the U.K. construction industry (Kirby and Watson [1999]) and the other in Australia with a convenience sample of franchisors (Frazer [2001]. These studies suggest that chains mainly discontinue franchising due to difficulties in recruiting and monitoring franchisees to ensure performance. Frazer [2001] also finds that the economic climate affects these decisions.

${ }^{25}$ See Stanworth et al. [1998] for further data and discussion on this topic.
} 
sales staff development and training. Since these amounts are substantial, we do not expect the decision to begin and exit franchising to be made lightly.

Focusing on the franchising component of the chains, we set exit from franchising $\left(\right.$ FExit $\left._{t}\right)$ equal to 1 in the year when the chain disappears from all our franchising directories and 0 otherwise. In total, we find 1,409 cases of exit from franchising in our data. We define franchising growth $\left(\right.$ FGrowth $\left._{t}\right)$ as the proportional change in the number of (only) franchised outlets in the chain, namely:

$$
\begin{aligned}
\text { FGrowth }_{t}= & 100 *\left(\text { Franchised Outlets }_{t+1}\right. \\
& \left.- \text { Franchised Outlets }_{t}\right) / \text { Franchised Outlets }_{t}
\end{aligned}
$$

and set FGrowth ${ }_{t}=-100 \%$ when FExit $_{t}=1 .^{26}$ This measure, like all our dependent variables, is forward looking. This is because in the theoretical models, firms decide on their output (and thus growth), and whether to exit or not, at the beginning of period $t+1$ based on the information available at time $t$.

Since franchised chains also include company-owned outlets, and can exit franchising but continue to operate as corporate entities, to provide a complete picture of chain dynamics, we also measure chain growth in terms of the change in total outlets $\left(\right.$ TGrowth $_{t}$ ):

$$
\begin{aligned}
\text { TGrowth }_{t}= & 100 *\left(\text { Total Outlets }_{t+1}\right. \\
& \left.- \text { Total Outlets }_{t}\right) / \text { Total Outlets }_{t}
\end{aligned}
$$

where Total Outlets $\mathrm{t}_{\mathrm{t}}=$ Franchised Outlets $_{\mathrm{t}}+$ Company-Owned Outlets $_{\mathrm{t}}$. Though we do not have direct information on whether the chain continues to exist or whether it fails altogether after it stops franchising, we can ascertain whether it has any company-owned outlets at the time it leaves franchising. ${ }^{27}$ In those cases where a chain has none, we assume that stopping franchising also implies going out of business, and we set 'total exit' (TExit ${ }_{t}$ ) equal to 1, and TGrowth ${ }_{t}$ equal to -100 . We have only 341 such exits, reflecting the fact that about one quarter of franchisors in our data are fully franchised (i.e., have no company outlets). ${ }^{28}$ Given the small number of exits we obtain

\footnotetext{
${ }^{26}$ There are 1,454 cases where FGrowth $=-100$ but only 1,409 cases when FExit $=1$, because the chain has not exited franchising according to our definition. In other words, these chains close down or convert all their franchised outlets, so their franchise growth is minus 100 , but they still appear in franchise directories. These observations are treated as being censored at the value -100 in the growth analyses, but not as exits in the exit regressions.

${ }^{27}$ We could use Yellow Pages to determine if we can still find outlets operating under the trade name today, for example, but no data source would allow us to go back to 1980 and track them over time to determine when exactly all outlets cease to exist if they do.

${ }^{28}$ Estimates from the literature suggest that about one out of every four franchisors has no corporate unit. Thus our sample, with 341 such firms out of 1,409 , is not unusual in this. See Blair and Lafontaine [2005] for more on this.
} 
TABLE I

Descriptive Statistics

\begin{tabular}{|c|c|c|c|c|c|}
\hline Variable Name (Definition) & Obs. & Mean & Std. Dev. & Minimum & Maximum \\
\hline Exit from Franchising (FExit) & 15404 & 0.09 & 0.29 & 0 & 1 \\
\hline Exit from Business (TExit) & 14445 & 0.02 & 0.15 & 0 & 1 \\
\hline $\begin{array}{l}\text { Growth in Franchised Outlets, in \% } \\
\text { (FGrowth) }\end{array}$ & 15404 & 10.30 & 68.67 & -100 & $500^{\ddagger \ddagger}$ \\
\hline Growth in Total Outlets, in \% (TGrowth) ${ }^{\dagger \dagger}$ & 14445 & 14.52 & 52.16 & -100 & $500^{\ddagger \ddagger}$ \\
\hline Survivor FGrowth & 13995 & 21.41 & 61.98 & $-100^{\ddagger}$ & $500^{\ddagger \ddagger}$ \\
\hline Survivor TGrowth & 14104 & 17.29 & 49.61 & -94.03 & $500^{\ddagger \ddagger}$ \\
\hline Size - Franchised Outlets (in 10s) & 15404 & 17.51 & 66.08 & 0 & 2053.1 \\
\hline Size - Total Outlets (in 10s) & 14445 & 21.88 & 80.61 & 0.1 & 2658.8 \\
\hline Age - Years in Franchising & 15404 & 10.99 & 9.92 & 1 & 76 \\
\hline Age - Years in Business & 14445 & 17.60 & 15.11 & 1 & 174 \\
\hline Business Experience Before Franchising & 15404 & 6.64 & 11.17 & 0 & 165 \\
\hline Percent Company Owned Outlets & 15404 & 20.23 & 26.67 & 0 & 100 \\
\hline Canadian & 15404 & 0.11 & 0.32 & 0 & 1 \\
\hline Franchise Fee $(\$ 100 \mathrm{~K})$ & 15404 & 0.20 & 0.13 & 0 & 3 \\
\hline Capital Required (\$100K) & 15404 & 1.89 & 6.57 & 0 & 290 \\
\hline Royalty Rate (\% of sales) & 15404 & 4.97 & 2.70 & 0 & 30 \\
\hline Advertising Fee ( $\%$ of sales $)$ & 15404 & 1.57 & 1.78 & 0 & 15 \\
\hline Monthly Ongoing Fixed Fee ( $\$ 000)$ & 15404 & 0.04 & 0.23 & 0 & 6.25 \\
\hline
\end{tabular}

$\dagger:=-100$ if FExit $=1 ;{ }^{\dagger \dagger}:=-100$ if TExit $=1$

‡. $-100 \%$ occurs for those chains that cancelled all franchised outlets, but are not exitors according to the data sources, so FGrowth $=-100 \%$, even though FExit $=0$.

ł‡: Observations with growth rates above $500 \%$ are excluded from the sample. See text.

with this definition, we interpret this measure as a lower bound on chains' actual business failure, whereas we view exit from franchising (FExit, as defined above) as an upper bound measure of the same. In those cases when the chain no longer is found in any of our directories, we have no data to measure its growth post exit from franchising. Thus we treat TGrowth $_{t}$ as missing and the observation as censored in the survival analyses.

We exclude from our sample the few observations where chain growth is above $500 \%$, as we suspect that these are due to coding errors or overly optimistic forecasts. ${ }^{29}$ Due to this, and to differences in definitions, the sample sizes differ depending on whether we measure only the franchising or all operations of the chain, as shown in our summary statistics in Table I. Most of the reduction in sample size from our initial 22,216 observations, however, is due to the requirement that we have at least two data points per chain to measure growth or survival as well as additional data cleaning and missing values for some control variables (see the data appendix).

\footnotetext{
${ }^{29}$ This eliminates 131 observations for FGrowth, and 59 observations for TGrowth. Most of these are for very small franchisors. Since some of the survey data is not verified by the publication, we suspect that these very high growth rates were due to typos or forecasts rather than the actual information that franchisors were supposed to report.
} 


\section{III(ii). Chain Age and Size}

The fact that franchised chains usually are comprised of both corporate and franchised outlets also affects how one measures their age and size. In all analyses, when our dependent variables are for the franchising component of the chain, we measure chain size by its number of franchised outlets only. When the dependent variables refer to both corporate and franchised operations, we measure chain size using total outlets, franchised and company owned. ${ }^{30}$ Moreover, as mentioned earlier, franchised chains usually begin their businesses by operating at least one outlet corporately for a few years before they start franchising. As a result, we also measure chain age in two ways: as the number of years that the firm has been franchising, and as the number of years since it started its first company outlet. We use the former in regressions where our dependent variables are about the franchising component of the chains only, and the latter when the dependent variables are about total chain operations.

While in theoretical models of firm dynamics, age and size often are viewed as equivalent summary statistics for 'firm efficiency/productivity,' and empirically these variables are usually highly correlated, in our data the correlations are 0.33 between years of franchising and number of franchised outlets, and 0.25 for the 'total-chain' measures. This is because we have many old chains that are still small, and large chains among the very young as well. Though there is a general tendency to associate franchising mostly with established chains, the reality is that the majority of franchised chains are quite young. In our sample, more than 50 per cent of the chains are young (7 or less years in franchising). Table I shows descriptive statistics for all the variables above in our final samples, as well as all the control variables, described in the next section, that are not series of dummy variables.

\section{III(iii). Control Variables}

As mentioned in our introduction, there has been some concern in the literature that the significant effects of age and size on growth and exit may

\footnotetext{
${ }^{30}$ While the theoretical models are about output levels, many empirical studies use sales or revenues as a measure of output. We believe that measuring chain size via the physical number of outlets is preferable in our context for several reasons. First, the number of outlets is a measure that the chains and trade press emphasize a lot; second, sales and value added can differ importantly in retailing. In other words, higher sales do not necessarily imply higher levels of 'real output' or economic activity (e.g., sales in a travel agency vs. a car dealership, or luxury vs. economy hotel chains). The number of outlets in a chain, however, captures variation in output levels quite well, not only across industries, but also between and within the chains in the same industry. Finally, we prefer the number of outlets also to an alternative-employment - used in some studies. We do not have outlet/chain employment data, but if we did we would hesitate to use this because, unlike the situation in manufacturing, many retail chains rely on seasonal workers and thus employment figures may suffer from serious measurement errors. See, e.g., Lafontaine and Sivadasan [2009] for analyses of labor costs in fast-food and their variability over time (and across countries).
} 
be due to other factors correlated with these variables but omitted from the analyses. Indeed, as emphasized still by Geroski et al. [2003], few authors have analyzed how firm characteristics beside age and size, including firm unobserved [by the econometrician] heterogeneity, might affect survival and growth, or how these might affect the observed relationship between a firm's age and size and its survival and growth. ${ }^{31}$

Fortunately, the rich panel nature of our data allows us to control for both observed and unobserved firm characteristics. We explain further in our methodology section how we incorporate firm unobserved heterogeneity in our linear and non-linear estimations. Here, we discuss how we control for the impact of other observed (and thus directly measurable) chain characteristics besides size and age, as well as the impact of other factors that may affect chain dynamics. This is important not only because it addresses a deficiency in the empirical literature, as just noted, but also because in the literature on franchising, authors have examined how contracting practices - such as the extent to which a chain relies on company ownership versus franchising and the terms of franchise contracts - affect firm performance, where the latter often is measured in terms of firm growth and survival. ${ }^{32}$

Our data include both time-varying chain characteristics as well as some characteristics that do not vary over time within chains. Among the first set, we have annual data on the franchise contract terms for each chain. These are expected to affect the profitability of a chain and thus the financial position of a franchisor, as well as franchisees, and thus the incentives to grow the chain and remain involved in franchising. ${ }^{33}$ Franchise contract terms include the royalty and advertising rates, both of which are usually stated and calculated as a percentage of outlet sales. They also include two types of fixed fees, namely the upfront franchise fees that franchisors typically request once, at the beginning of the 15 to 20 year franchise relationship, as well as, in some cases, ongoing fixed payments which are requested instead of, or in addition to, royalties or advertising fees based on sales. We measure both types of fixed fees in thousands of nominal U.S. dollars, but ongoing fixed fees are further expressed as per month requirements.

In addition to contract terms, we have data on the amount of capital required to open an outlet and on the proportion of company-owned outlet in each chain, both of which can change from one year to the next. We

\footnotetext{
${ }^{31}$ To our knowledge, only Disney et al. [2003] and Jarmin et al. [2004] have followed suit at least to some degree - similarly as Dunne et al. [1989] both studies controlled for whether an establishment belongs to a single or multi-unit firm.

${ }^{32}$ See notably Shane [1996], Lafontaine and Shaw [1998] and Azoulay and Shane [2001].

${ }^{33}$ In Jovanovic's model, firms learn/update their expectations about their efficiency based on profits earned at the end of each period. Thus only more profitable firms grow and survive. The importance of financial resources for firm growth and survival is documented in a vast literature in finance. For details on franchise contracts, and their role in affecting the performance of franchised businesses, see Lafontaine [1992] and Blair and Lafontaine [2005]. 
include the former, also expressed in thousands of nominal U.S. dollars, to control for potential differences in outlet sizes across chains. As for the proportion of company-owned outlets, Lafontaine and Shaw [2005] discuss how franchisors try to achieve a stable mix of franchised vs. company-owned units in the long run, which affects whether more franchised or company outlets will be opened in any given year, and thus might differentially affect our two measures of chain growth and exit. Further, to avoid possible biases due to common macro-economic shocks - e.g. changes in aggregate demand, inflation, institutional/regulatory changes, and so on - that could drive chain growth or failure over time, we include a series of yearly dummy variables in all our regressions.

The chain characteristics that are constant over time in our data include first the state in which the franchisor's headquarter is located. We use this to generate a series of dummy variables that we include in our empirical model because smaller franchisors tend operate outlets mostly in their state of headquarter, and different states have different regulations for franchised businesses. These dummy variables also control for location-specific fixed effects (e.g., different demographics or weather across states) that may affect chain growth or survival. Since our data include both U.S. and Canadian franchisors, we also include a separate Canadian franchisor dummy variable to control for different business and regulatory conditions between the two countries.

Since chains that operate for a longer period of time before becoming involved in franchising can benefit from the reputation, business acumen or pool of customers developed during this period, in regressions focusing on franchised only versions of our dependent variables, we also control for the number of years that the chain was in operation before it started franchising (Business Experience $=$ Years in Business - Years in Franchising).

Finally, for each chain, we know the type of activities that it is engaged in, which we classify among 23 sectors (see Appendix Table AI). We include a series of sector dummy variables in all our regressions to control for unobserved (to the econometrician) sector-specific factors, such as, for example, different levels of demand for the product, different levels of competition, or different cost factors (e.g., issues related to specific inputs, types of human capital requirements, particular types of location requirements, and so on). Ultimately, we control for unobserved chain-specific heterogeneity via the methodology described in Section IV(ii), which further alleviates concerns that differences within sectors or chain-specific variation (e.g., hotel vs. bagel shop) might affect our results.

Table AI, in the appendix, shows descriptive statistics for all our variables on a per sector basis. It makes clear that there is much variation across sectors, starting with the number of franchised chains per sector which varies from a low of just 20 to 30 chains (in the Repair and Travel sectors) to a high of more than 400 chains (in the fast food, or Eating Places - Limited Service, 
Retail - Other and in the Business Services sectors). In addition, the table shows sizable differences in the characteristics of chains across sectors. For example, average chain size is much greater, at more than 300 outlets per chain, in the Maintenance, Hotels and Motels, and fast-food sectors, than in the Education, Personal Services or Contractors sectors where chains have on average fewer than 100 outlets. Average chain age also differs importantly across sectors. Similarly for the proportion of company-owned outlets, which varies from $7.4 \%$ (Travel) to $31.7 \%$ (Eating Places - Full Service), as well as other contract terms. Given this variation, we conclude that controlling for unobserved sectoral differences in our analyses is important, as our estimates would be biased otherwise. And indeed, consistent with our expectations, in all regressions where we can separate their impact from unobserved chain heterogeneity, we find that the sectoral dummy variables are jointly significant. As described further below, to verify the robustness of our results, we also carried out several sectoral analyses. We found those to be qualitatively equivalent to the results we present below.

\section{METHODOLOGY AND RESULTS}

\section{IV(i). Cross Sectional Data Patterns}

We begin our analyses of the relationship between chain age and size and their survival and growth by showing cross-sectional means in Figures 1-4. Figures 1 and 2 show the relationship between average growth rates and chain size and age, grouped by cohorts. ${ }^{34}$ The first panel in each figure considers Total Growth (TGrowth) as a function of total years in business or total outlets, while the second panel shows growth in Franchising (FGrowth) as a function of years in franchising or number of franchised outlets.

Figures 1 and 2 show a systematic negative relationship between growth rates and both age and size, whether we focus on the overall, or just the franchising components, of the chains.

Figures 3 and 4 show the relationships between exit rates and chain age and size respectively. These also show a decreasing proportion of chains exiting as they become better established along either the age (negative duration dependence) or size dimension. For both growth and exit, the effects are much smaller, however, after the chains have achieved some level of maturity or size. Since these figures only show average growth and exit

\footnotetext{
${ }^{34}$ Age cohorts are defined as 1: 1 year, 2: 2-3 years, 3: 4-6 years, 4: 7-10 years, 5: 11-15 years, 6: 16-20 years, 7: 21-30 years, 8: 31-40 years, 9: 41-50 years, $10: 51-70,11: 71+$ years. As for size, we use $1: 1-2$ outlets, $2: 3-5$ outlets, $3: 6-10$ outlets, $4: 11-20$ outlets, $5: 21-30$ outlets, $6: 31$ 50 outlets, 7: $51-100$ outlets, 8 : 101-200 outlets, $9: 201-300$ outlets, $10: 301-500,11: 501-1000$, 12: $1001+$ outlets.
} 

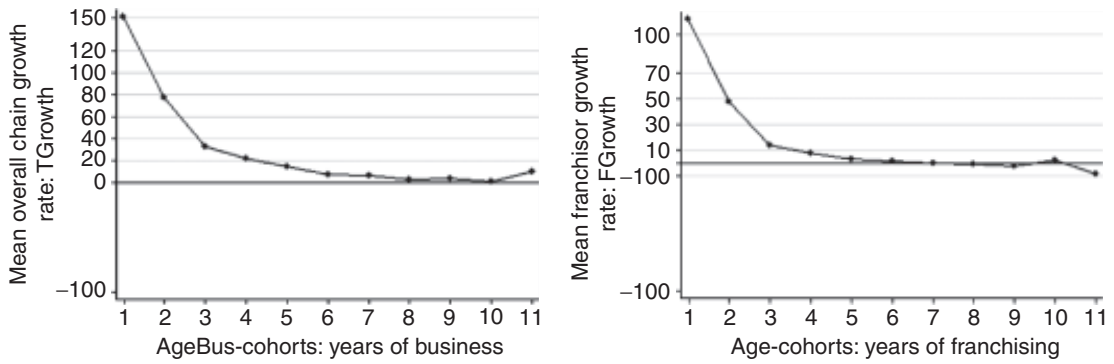

Figure 1

Average Growth Rate as a Function of Chain Age
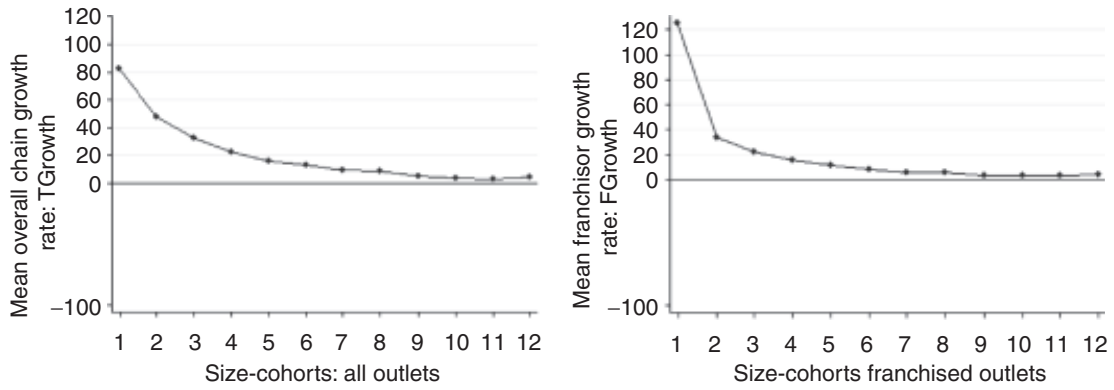

Figure 2

Average Growth Rate as a Function of Chain Size
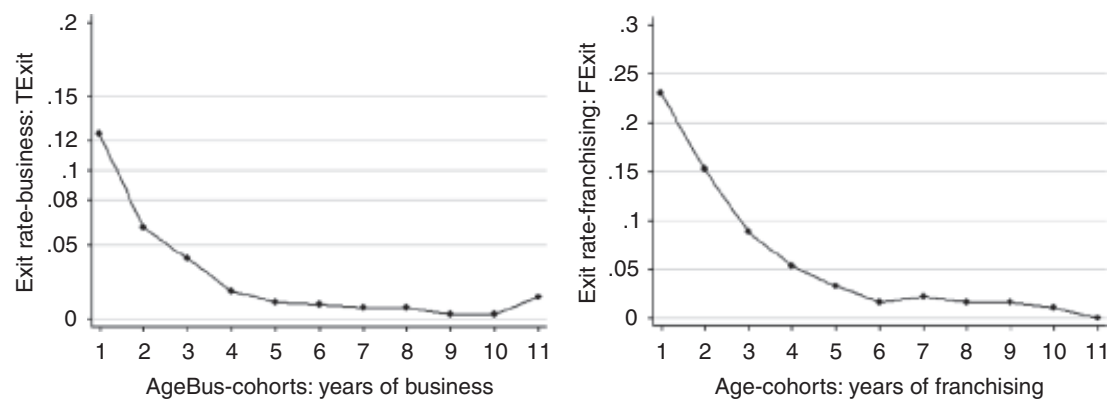

Figure 3

Exit Rates as a Function of Chain Age

rates as a function of chain age and size without taking into account the impact of other factors, we now turn to duration and growth rate analyses with additional chain-level control variables to explore these relationships in more detail. 

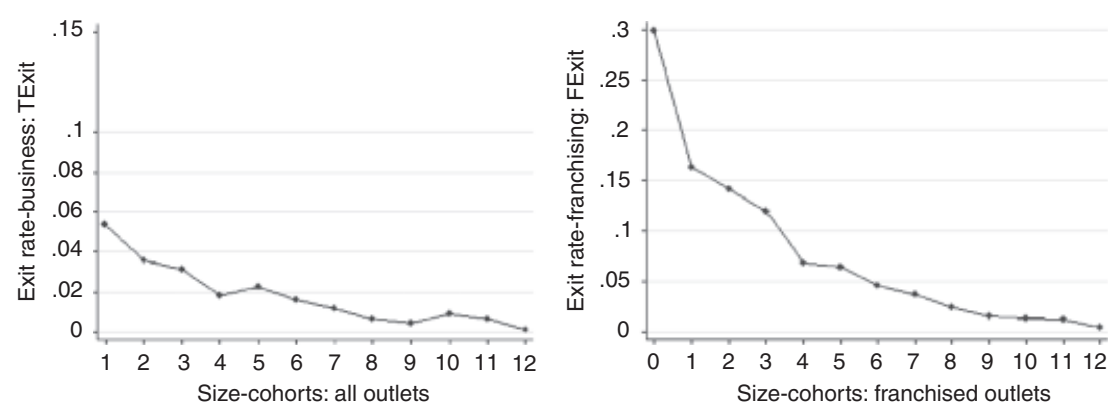

Figure 4

Exit Rates as a Function of Chain Size

\section{IV(ii) Chain Growth}

Our measures of growth have a lower bound at $-100 \%$, when chains exit, indicating left censoring in the data. We therefore estimate the growth equation using a Tobit model. However, although in general the linear models (fixed and random effects) provide inconsistent estimates when the dependent variable is censored as it is here, they still provide a useful benchmark for the marginal effects near the population means without imposing the distributional assumptions that the Tobit model requires (e.g., see Wooldridge [2002]). Also when censoring is low, the bias in linear models is negligible. For these reasons, we also present results from standard linear fixed-effects estimation. To highlight the similarity between Tobit and the linear fixed-effects estimates, we report estimated coefficients from the Tobit regressions. The (unreported) marginal effects in Tobit, evaluated at sample means, were almost identical to the reported coefficients.

Unobserved differences across chains, especially differences in product type, product quality or appeal, may bias our estimates if we do not control for chain-specific heterogeneity. For example, the long-run demand for niche products such as bubble tea shops is likely to be lower than for more mainstream products such as coffee shops. When franchisors develop new products or explore new niches, they cannot know ahead of time whether a new product category will turn out to be a fad (e.g., restaurants catering to followers of the Atkins diet), nor how much competition they will face ultimately in their product categories (e.g., bagel shops). Chain-specific effects control for all such prior expectations for a franchised chain at the time of entry. They also control for unobserved differences across chains in monitoring practices and intensity of agency problems, the timing of entry relative to other chains in the same industry, differences in access to capital or technology that may arise from a chain's belonging to a larger franchise company or not, or any other differences in initial conditions. In particular, the growth and survival of any given single-product chain in the firm's 
portfolio may be affected not only by the chain's characteristics, but also by the franchising firms' profit maximization process across its multiple chains/ brands. ${ }^{35}$ For all these reasons, we expect it to be particularly important to control for this heterogeneity or chain-specific effects in our analyses.

Since the unobserved chain effects are expected to be correlated with other chain characteristics, including age, size, and contracting practices, we cannot treat them as random effects in our estimations. Hausman tests comparing results from linear fixed and random-effects models always rejected the random effects specification, confirming our expectations that the chain unobserved heterogeneity in our data is correlated with the regressors. To correct for such correlated unobserved chain heterogeneity (or chain 'fixed effects') in Tobit, we follow the methodology suggested in Wooldridge [1995, $2002 \mathrm{ch} .16)$ and Mundlak [1978]. ${ }^{36}$ Specifically, we assume that chain unobserved heterogeneity $\left(\mu_{i}\right)$ can be modelled as $\mu_{i}=\bar{X}_{i} \xi+a_{i}$, where $\bar{X}_{i}$ is the vector of the chain-level means of all chain time-varying characteristics $\left(X_{i t}, t=1, . . T_{i}\right)$ included as a set of additional controls in the standard Tobit model, and $a_{\mathrm{i}}$ represents the part of chain unobserved heterogeneity that is assumed uncorrelated with the regressors. ${ }^{37}$

Since Tobit estimates are inconsistent in the presence of heteroscedasticity - a problem that is likely to arise due to the non-linear impact of age and size on growth rates (e.g., Evans [1987a]) - we include quadratic terms in chain age, size and their cross effect in our regressions. As noted earlier, we also exclude outliers with growth rates $>500 \%{ }^{38}$

Table II, columns 1 and 2, show results from (chain fixed-effects adjusted) Tobit and standard linear fixed-effects model for Franchising Growth (top panel), and Total Growth (bottom panel). As mentioned above, all regressions include survey year dummy variables. In addition, Tobit specifications include sector, headquarter state and Canadian dummy variables (all of which are differenced out in linear fixed-effects models).

\footnotetext{
${ }^{35}$ For more on multi-chain ownership, see Kosová, Lafontaine and Zhao [2009].

${ }^{36}$ Mundlak [1978] shows that the results from standard linear fixed-effects models can be obtained via random effects estimations when firm-level means of time-varying regressors are added as additional controls. Wooldridge [1995, 2002 ch.16] recommends using this idea in non-linear models (probit/tobit) as it is impossible to difference out fixed effects in these as is done in standard linear fixed-effects model. This approach by definition excludes means of time-invariant chain characteristics (i.e., business experience or location of headquarters or Canadian dummy variable, as well as sector dummy variables), but also means of aggregate dummy variables such as survey year.

${ }^{37}$ We also estimated Random Effects Tobit models to allow for uncorrelated chain-level unobserved heterogeneity $\left(a_{i}\right)$ in the error term, but the results were very similar to those we report for pooled Tobit.

${ }^{38}$ Before outliers were excluded, robust standard errors from linear fixed-effects models were different from their non-corrected counterparts, suggesting that heteroscedasticity was a problem in our data. After the outliers were excluded, the standard errors between these two specifications were similar. Hence, excluding the outliers reliably addressed the heteroscedasticity problem that would otherwise have biased the tobit estimations.
} 
TABLE II

Chain Age and Size Effects on \% Growth and Exit

(ALL SPECIFICATIONS CONTROL FOR CHAIN UNOBSERVED CORRELATED HETEROGENEITY)

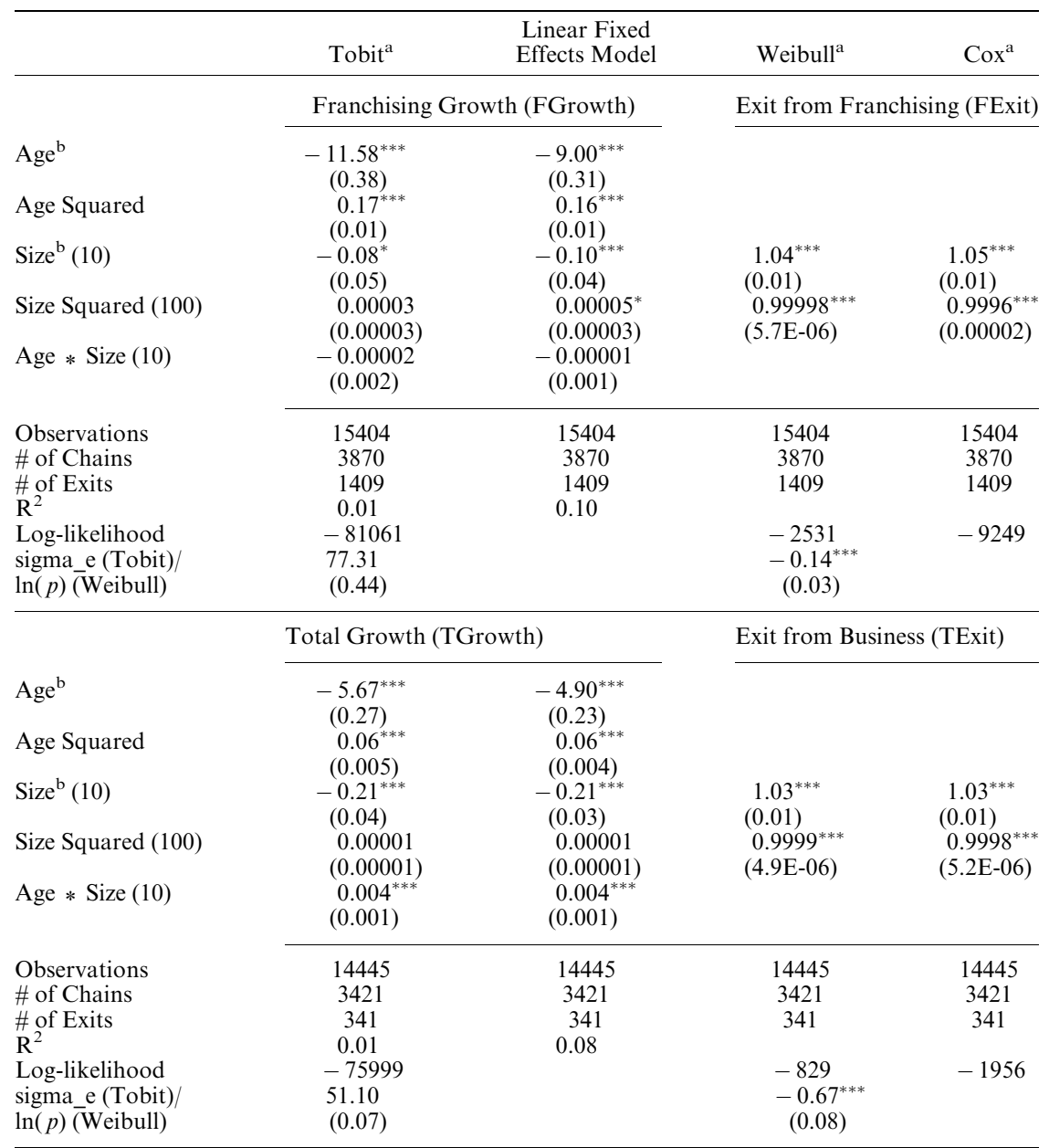

${ }^{a}$ We control for chain-level unobserved correlated heterogeneity per Wooldridge [1995, 2002].

${ }^{\mathrm{b}} \mathrm{Age}$ (size) refers to years since the chain began franchising (number of franchised outlets) in the upper panel and to the number of years since the chain started operating (total number of outlets) in the bottom panel.

Standard errors in parentheses. Significant at: * $10 \% ;{ }^{* *} 5 \% ;{ }^{* * *} 1 \%$. In columns 3-4 exponentiated coefficients and robust standard errors calculated by the Delta method (adjusted for heteroscedasticity and chain-level clusters) reported. In these columns the levels of significance are assessed based on original coefficients and standard errors (see text). All regressions contain survey year dummy variables. In addition, Tobit and exit specifications include sector, franchisor headquarter state and Canadian dummy variables. In Linear Fixed Effects regressions, these are differenced out. 
Results in Table II are quite consistent in terms of sign and significance levels for both measures of growth, and the different corresponding definitions of chain age and size. As predicted by Jovanovic-type learning models and evidenced in the literature on manufacturing firms, chain age and size have sizable, and statistically significant, negative effects on growth. In particular, the negative linear effects of age and size dominate the opposite sign quadratic effects: holding all variables at their mean values, the net effect of increasing chain age (years in business) by a single year in column 2 of Table II in the bottom panel is to reduce the growth rate (TGrowth) by 2.7 percentage points. Increasing total chain size by 10 outlets, on the other hand, reduces the growth rate in the net by 0.14 percentage points. ${ }^{39}$ These are economically important effects given a mean 'total' growth rate of 14.52 per cent (Table I). Most importantly, we find these effects even after controlling for unobserved chain heterogeneity. Finding a negative impact of chain size on growth while controlling for chain fixed effects suggests that there is convergence in our data to chain-specific sizes. ${ }^{40}$ We come back to this issue later, when we discuss results for the subsample of mature chains.

\section{IV(iii). Chain Exit}

Given that Figure 3 suggests negative duration dependence, we rely on a Weibull specification for our exit analyses, which allows us to test for such dependence. As a robustness check, we also report results from a Cox model, which has the advantage that it does not rely on distributional assumptions. $^{41}$

In a Weibull model, survival time $\mathrm{S}$ (let's denote its particular value s), measured by age, follows the distribution $f(s)=p \cdot s^{p-1} e^{\left(X \beta-s^{p} e^{X \beta}\right)}$, where $f$ denotes the extreme value density function, $X$ is the vector of regressors (with subscripts $i$ for chain and $t$ for year omitted for simplicity) and $p$ represents the duration parameter in the baseline hazard. If $p<1$ (or $\ln (p)<0$ ), we have negative duration dependence, meaning that older chains have lower exit rates, whereas $p=1$ or $p>1$ indicate no or positive duration dependence, respectively. The Weibull model exhibits the 'proportional hazard rate' property, i.e., its hazard function, which is the rate at which a chain exits given it has survived until time s, can be written as

\footnotetext{
${ }^{39}$ The net effect of Age (Years in Business) on Total Growth is ( $\partial$ TGrowth/ $\partial \mathrm{Age})=\left[b_{\text {Age }}+2 b_{\text {sq.Age }}\right.$ mean $($ Age $)+b_{\text {Age } * \text { Size }}$ mean $($ Size $\left.)\right]$, where sample mean $($ Size $)=21.9$ measured in 10's, and mean(Age) $=17.6$, per Table I.

${ }^{40}$ See Geroski et al. [2003] for more discussion, especially on the difference between firmspecific and overall convergence in firm size. Our results support the former, not the latter.

${ }^{41}$ One drawback of the Cox model for our purposes is that it does not allow us to test for negative duration dependence, as predicted by Jovanovic's [1982] model. Also, if the Weibull distribution fits the data well, the estimates from the Weibull will be more efficient.
} 
$h(s)=h_{0}(s) e^{X \beta}$. Thus changes in regressors shift the baseline hazard, $h_{0}(s)$, and the exponentiated coefficients capture the effect of a one unit increase in a particular variable on the exit hazard ratio. ${ }^{42}$ The Cox proportional hazard model (Cox [1972]) also satisfies this property. ${ }^{43}$ Given this, to facilitate interpretation, we report exponentiated coefficients in the tables below. If the reported coefficient $(b)$ is greater than one, the difference $(b-1) 100$ indicates a percentage by which a given variable increases the exit rate. Similarly, if $b<1$, the difference $(1-b) 100$ represents the percentage reduction in the exit rate that would result from a one unit increase in the variable. The reported standard errors are calculated by the Delta method and adjusted for heteroscedasticity and chain-level clusters. ${ }^{44}$ As is standard in survival analyses, due to the skewed distribution of the exponentiated coefficients, the levels of significance indicated by stars in the table - are assessed based on original coefficients and standard errors.

Two data issues affect our exit estimations. In our sample there are 1,409 exits from franchising (FExit) and 341 total exits (TExit). Since we know when the chains started in business and began franchising, we have complete duration spells for the chains that we see exiting during our sample period. For non-exiting chains, however, duration spells are incomplete and observations are right censored. In addition, there are chains that operated for several years before entering our sample. But a chain can enter our sample for example at age $=6$ only if it has survived this long. The presence of such chains in the data could introduce survivorship bias in our estimations. We control for survivorship bias (or left truncation) by conditioning the maximum-likelihood function on the age at which a chain enters our sample, and for data censoring by conditioning on whether an observation is right censored or not.

Results from both the Weibull and Cox models are shown in Table II, in columns 3 and 4 respectively, and again focusing on franchising only (FExit) in the top, and total business (TExit) in the bottom panel of the table. All regressions again include sector, state of franchisor headquarter, Canadian and year dummy variables. Also, since the growth results indicated the presence of chain-level unobserved correlated heterogeneity, we correct for

\footnotetext{
${ }^{42}$ Suppose that we have only one covariate, $\mathrm{X}$, that we increase by 1 unit. The ratio of exit hazards after and before this change can be expressed as a function of the coefficient of $\mathrm{X}$, namely: $\frac{h(s \mid X+1)}{h(s \mid X)}=\frac{h_{0}(s) e^{(X+1) \beta}}{h_{0}(s) e^{X \beta}}=e^{\beta}$.

${ }^{43}$ We use Efron's approximation to handle tied exits in the Cox model - see Hosmer and Lemeshow [1999, p. 107] for the partial likelihood function adjusted for this approximation.

${ }^{44}$ Besides controlling for chain correlated unobserved heterogeneity (chain fixed effects) we also allow for random effects ('uncorrelated' heterogeneity) in the error terms and adjust the standard errors for chain-level clusters.
} 
this in our exit regressions using the methodology suggested by Wooldridge [1995, 2002 ch.16] (see Section IV(ii)).

Consistent with our growth rate results, we find that both chain age (per the coefficient $\ln (p)$ in the Weibull model) and size matter even when we control for chain-specific effects. Since firm age and size affect survival rates and growth because they capture the intrinsic 'efficiency' of the firm learning-based models, and we control for such efficiency via the chainspecific effects, we can conclude that firm unobserved efficiency and the associated learning process are not the only mechanism through which age and size affect chain dynamics. Also, the coefficients on squared terms are of opposite signs, but the linear effects always dwarf the non-linear ones. Thus, consistent with theory and previous empirical studies, we conclude that chain age has a negative effect on exit. However, chain size has a positive rather than negative effect on exit. In other words, within chains, growing larger increases the likelihood of failure, a finding that contradicts Jovanovic [1982] learning-type models, as well as current stylized facts in the empirical literature. In the next section, we explore whether, as suggested by e.g., Klepper and Thompson [2006], our results may be due to other factors that would be correlated with age and size, but are omitted from our simple regressions above.

\section{IV(iv). Controlling for Observed Chain Characteristics}

Unlike most other studies on firm dynamics, our data have the advantage of including detailed characteristics for each chain. It is of interest to consider how the introduction of these chain characteristics - beyond industry sector and state of headquarter - not only affect the results above, but also directly affect chain growth or survival. Of course, it is also important to recognize that control variables such as the proportion of company outlets and the terms of the franchise contracts reflect decisions made by company managers. Following the sequence of events in Jovanovic's [1982] and similar learning-based models, contracting practices measured at time $t$ are predetermined at the beginning of period $t+1$ when the chain chooses its output (growth) or makes its exit decision. In that sense, the regression coefficients for these control variables are consistent. Still, one might be concerned that the observed correlations between contracting variables and, say, survival might be due to unobserved factors that affect both contract terms and chain survival. For example, high quality franchisors may choose high fees (franchise fees and royalty rates) or require high levels of investments, and at the same time these high-quality chains will tend to survive longer and grow faster. If we do not control for chain quality, the coefficients of the fees might be biased downward (e.g., without fixed effects, higher franchised fees would reduce, not increase, FExit). Assuming that chain quality is constant over time, which is likely given that it represents the 
appeal of the chain's concept or product, or that the probability that a new product concept is not just a fad is constant over time, then controlling for chain unobserved correlated heterogeneity (or chain 'fixed effects') as was done above alleviates this concern.

We show results obtained after adding contracting practices and our other chain characteristics to our growth regressions in Table III, and for our exit regressions in Table IV, columns 1-4.

These results show that controlling for other chain characteristics affects the magnitudes of our estimates in Table II, especially the impact of age on FGrowth and FExit. Without the control variables (Table II) the chains show stronger negative duration dependence (per the $\ln (p)$ coefficients in the exit regressions). Also, one more year of franchising has a greater negative impact on the franchising growth rate $(5.5$ vs. 4.4 percentage points, at the mean of $10.3 \%$ ) per the linear fixed-effects growth equation results. However, the inclusion of the control variables does not change our qualitative findings - the effects of age and size remain statistically significant, economically important, and of the same signs as in Table II. In particular, chain size continues to have a significant negative impact on growth - which confirms the convergence in size toward chain-specific sizes - and a positive effect on exit.

As for the effects of the contracting practices and chain characteristics themselves, in the growth regressions (Table III) we find first that the number of years that the franchisor spends developing the franchise concept before starting to franchise (Business Experience) has a strong positive effect on franchising growth, as expected. ${ }^{45}$ Larger proportions of company outlets in the chain are also positively related to growth, and this effect is particularly strong for franchising (as opposed to total) growth. This result contradicts the notion from the franchising literature that franchising allows chains to grow faster. It is consistent, however, with findings in Lafontaine and Shaw [2005] as it indicates that franchisors whose proportion of company outlets is 'unusually' high at a point in time tend to grow the franchised side of their businesses, most likely to get back to their target level of company ownership. ${ }^{46}$ The total growth in the chain then represents

\footnotetext{
${ }^{45}$ This variable does not appear in columns 3 and 4 because the time spent developing the franchise is included in the Age variable (i.e., Age $=$ Bus. Experience + years of franchising) in these columns. Moreover, its effect is subsumed in the chain-specific effects in the FixedEffects regression in column 2.

${ }^{46}$ For example, Accor North America - one of the largest hotel companies in the world recently announced the opening of 57 new hotels in North America, including 51 franchised and 6 company owned properties. According to Olivier Poirot, the CEO: 'Our growth plans in North America are consistent with Accor's philosophy to maintain balance as an owner/ operator, management partner and franchisor ... By increasing the growth of both franchised and corporately-owned locations in our network, Accor is getting closer to achieving our goal of reaching 1,200 North American properties by 2010' [HNN Hotelnewsnow.com, January 20, 2009, emphasis added].
} 
TABLE III

Chain \% Growth - Tobit and Linear Fixed Effects Model (ALL SPECIFICATIONS CONTROL FOR CHAIN UNOBSERVED CORRELATED HETEROGENEITY)

\begin{tabular}{|c|c|c|c|c|}
\hline & \multicolumn{2}{|c|}{ Franchising Growth (FGrowth) } & \multicolumn{2}{|c|}{ Total Growth (TGrowth) } \\
\hline & Tobit $^{\mathrm{a}}$ & $\begin{array}{l}\text { Linear Fixed } \\
\text { Effects Model }\end{array}$ & Tobit $^{\mathrm{a}}$ & $\begin{array}{l}\text { Linear Fixed } \\
\text { Effects Model }\end{array}$ \\
\hline $\mathrm{Age}^{\mathrm{b}}$ & $\begin{array}{c}-9.48^{* * *} \\
(0.38)\end{array}$ & $\begin{array}{c}-7.26^{* * *} \\
(0.30)\end{array}$ & $\begin{array}{c}-5.10^{* * *} \\
(0.27)\end{array}$ & $\begin{array}{c}-4.42^{* * *} \\
(0.23)\end{array}$ \\
\hline Age Squared & $\begin{array}{l}0.14^{* * *} \\
(0.01)\end{array}$ & $\begin{array}{l}0.13^{* * *} \\
(0.01)\end{array}$ & $\begin{array}{c}0.05^{* * *} \\
(0.005)\end{array}$ & $\begin{array}{c}0.05^{* * *} \\
(0.004)\end{array}$ \\
\hline $\operatorname{Size}^{\mathrm{b}}(10)$ & $\begin{array}{c}-0.07 \\
(0.05)\end{array}$ & $\begin{array}{c}-0.09^{* *} \\
(0.04)\end{array}$ & $\begin{array}{c}-0.21^{* * *} \\
(0.04)\end{array}$ & $\begin{array}{c}-0.21^{* * *} \\
(0.03)\end{array}$ \\
\hline Size Squared (100) & $\begin{array}{c}0.00002 \\
(0.00003)\end{array}$ & $\begin{array}{c}0.00004 \\
(0.00003)\end{array}$ & $\begin{array}{c}0.00002 \\
(0.00001)\end{array}$ & $\begin{array}{c}0.00002 \\
(0.00001)\end{array}$ \\
\hline Age $*$ Size $(10)$ & $\begin{array}{c}0.0004 \\
(0.002)\end{array}$ & $\begin{array}{c}0.0004 \\
(0.001)\end{array}$ & $\begin{array}{l}0.004^{* * *} \\
(0.001)\end{array}$ & $\begin{array}{l}0.004^{* * *} \\
(0.001)\end{array}$ \\
\hline Bus. Experience & $\begin{array}{l}0.11^{* *} \\
(0.05)\end{array}$ & & & \\
\hline Percent Co-own & $\begin{array}{l}1.74^{* * *} \\
(0.07)\end{array}$ & $\begin{array}{l}1.72^{* * *} \\
(0.05)\end{array}$ & $\begin{array}{l}0.56^{* * *} \\
(0.05)\end{array}$ & $\begin{array}{l}0.56^{* * *} \\
(0.04)\end{array}$ \\
\hline Capital Required & $\begin{array}{c}-0.27 \\
(0.28)\end{array}$ & $\begin{array}{c}-0.35 \\
(0.22)\end{array}$ & $\begin{array}{c}-0.09 \\
(0.20)\end{array}$ & $\begin{array}{c}-0.12 \\
(0.17)\end{array}$ \\
\hline Franchise Fee & $\begin{array}{r}-17.43^{*} \\
(10.22)\end{array}$ & $\begin{array}{r}-15.14^{*} \\
(8.00)\end{array}$ & $\begin{array}{c}-18.00^{* *} \\
(7.75)\end{array}$ & $\begin{array}{c}-16.72^{* * *} \\
(6.43)\end{array}$ \\
\hline Advertising Fee & $\begin{array}{c}0.13 \\
(0.76)\end{array}$ & $\begin{array}{c}0.21 \\
(0.59)\end{array}$ & $\begin{array}{c}0.57 \\
(0.56)\end{array}$ & $\begin{array}{c}0.59 \\
(0.46)\end{array}$ \\
\hline Royalty Rate & $\begin{array}{c}0.86 \\
(0.59)\end{array}$ & $\begin{array}{r}0.84^{*} \\
(0.46)\end{array}$ & $\begin{array}{c}0.37 \\
(0.45)\end{array}$ & $\begin{array}{c}0.38 \\
(0.37)\end{array}$ \\
\hline Ongoing Fixed Fee & $\begin{array}{r}8.65^{*} \\
(5.06)\end{array}$ & $\begin{array}{l}8.13^{* *} \\
(3.93)\end{array}$ & $\begin{array}{r}7.05^{*} \\
(3.79)\end{array}$ & $\begin{array}{l}6.65^{* *} \\
(3.14)\end{array}$ \\
\hline Canadian & $\begin{array}{c}-28.97 \\
(32.12)\end{array}$ & & $\begin{array}{c}-25.63 \\
(23.53)\end{array}$ & \\
\hline Constant & $\begin{array}{c}9.75 \\
(33.07)\end{array}$ & $\begin{array}{l}36.77^{* * *} \\
(4.18)\end{array}$ & $\begin{array}{c}33.26 \\
(24.22)\end{array}$ & $\begin{array}{l}60.17^{* * *} \\
(3.98)\end{array}$ \\
\hline $\begin{array}{l}\text { Observations } \\
\text { \# of Chains } \\
\text { \# of Exits } \\
\mathrm{R}^{2} \\
\text { Log-likelihood } \\
\text { sigma_e }\end{array}$ & $\begin{array}{l}15404 \\
3870 \\
1409 \\
0.01 \\
-80683 \\
69.41 \\
(0.43)\end{array}$ & $\begin{array}{c}15404 \\
3870 \\
1409 \\
0.19\end{array}$ & $\begin{array}{l}14445 \\
3421 \\
341 \\
0.01 \\
-75888 \\
50.72 \\
(0.30)\end{array}$ & $\begin{array}{c}14445 \\
3421 \\
341 \\
0.09\end{array}$ \\
\hline
\end{tabular}

${ }^{\mathrm{a}} \mathrm{We}$ control for chain-level unobserved correlated heterogeneity (i.e., chain fixed effects) as discussed in Wooldridge [1995, 2002] - see Sections IV(ii)-IV(iii).

${ }^{\mathrm{b}}$ Age (Size) refers to years since the chain began franchising (number of franchised outlets) in columns 1-2, but to the number of years since the chain started operating (total number of outlets) in columns 3-4.

Standard errors in parentheses. Significant at: ${ }^{*} 10 \% ;{ }^{* *} 5 \% ;{ }^{* * *} 1 \%$. All regressions contain survey year dummy variables. In addition, Tobit specifications include sector and franchisor headquarter state dummies. In Linear Fixed-Effects regressions, these are differenced out.

mostly the effect that the increased number of franchised outlets has on total chain size. Though these effects are not always statistically significant, we also find that higher capital requirements and franchise fees have a negative, while sales-based fees have a positive, effect on chain growth rates. These 


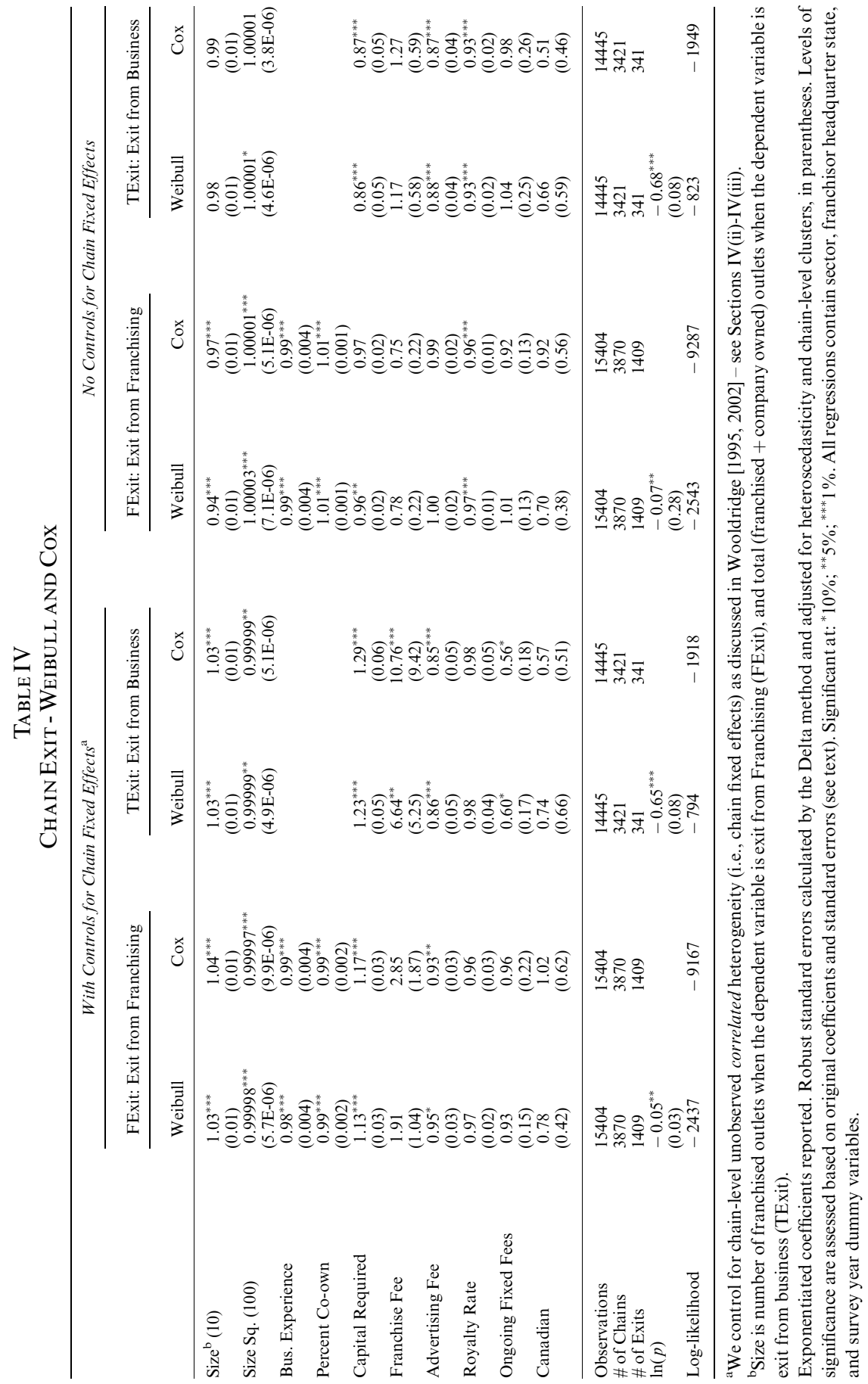


results suggest that ongoing revenue streams for franchisors, via royalties or other such fees, and low upfront requirements for franchisees, are most conducive to franchise chain growth.

In our exit regressions, in Table IV columns $1-4$, we find results for the control variables that are largely consistent with those we found for growth. In particular, the extent to which the chain took time to develop its business prior to franchising (Business Experience) and the extent to which it operates outlets corporately (Percent Co-Own) are both positively related to the likelihood that it remains in franchising. The effects are quite small, however, with a $1-2 \%$ decrease in exit rate for each extra year of business experience or percentage point increase in company ownership. ${ }^{47}$ Higher amounts of capital required to open each outlet in a chain, and higher franchise fees, increase the likelihood of exit, suggesting that it is more difficult for franchisors to find franchisees when the amount of capital required - and/or franchise fee - is relatively high. This lack of success in finding franchisees then increases the likelihood that the franchisor stops franchising and either continues to operate as a corporate chain, or goes out of business. Finally, though these effects are not always statistically significant, higher variable fees (royalty rates and advertising fees) tend to reduce the likelihood of chain exit from franchising. Thus, greater ongoing revenue streams for franchisors again increase the likelihood that the chain remains in franchising.

Overall, the results we obtain when including control variables point to important interactions among contracting practices and chain characteristics, and a clear direct impact of these variables on both growth and exit rates. However, the inclusion of these variables does not explain away any of our findings so far, including the anomalous positive impact of chain size on exit.

Since previous studies - traditionally focused on manufacturing data usually did not control for firm/establishment fixed effects, in columns 5-8 of Table IV, we explore whether our anomalous exit result might be driven by the inclusion of chain-level 'fixed effects.' We confirm that indeed, when we do not control for these, chain size has a negative impact on exit in all specifications, as in the prior literature. We conclude that our anomalous result for chain size is not due to the specifics of our retail-chain setting, but to the lack of firm fixedeffects in the prior empirical literature. Indeed, if firm size were positively correlated with unobserved firm heterogeneity such as quality of the firm, or the timing of entry within the 'industry life cycle' per Agarwal and Gort [1996, 2002], the coefficients on size in exit regressions that do not control for chain fixed effects would be biased downward. Our findings suggest that the results reported in prior studies may well be biased in this way.

\footnotetext{
${ }^{47}$ Since our measure of total exit implies that the proportion of company outlets equals 0 , any positive value determines survival perfectly so we cannot include this variable in our analyses of Total Exit (TExit) in Table IV. Similarly, business experience is part of age in analyses of TExit. 
IV(v). Robustness Checks

Although we do not report these, we performed several analyses to verify the robustness of our results. In addition to estimating our empirical models using different approaches and specifications, as described above, we also examined how our results might differ across industry sectors in our data. ${ }^{48}$ Indeed, although all our estimations control for chain correlated unobserved heterogeneity (i.e., chain specific effects), and all non-linear specifications (i.e., those that do not rely on data de-meaning) include sectoral dummy variables - all of which should reliably capture systematic differences across the 23 sectors in our data - it might still be that our results are not general, but instead are driven by data patterns peculiar to just a few sectors. Our within-sector results for the growth equation, however, were consistent across sectors, and with those we report. ${ }^{49}$ Moreover, to make sure our results were not driven by the few sectors with greater numbers of chains in our data, we estimated all our models for a subsample that excluded the three sectors with more than 400 chains (namely Business Services, Fast-Food and Retail - Other - see Table AI in the appendix). Again, results for this subsample were very consistent with those we report. We conclude that our results are not driven by just a few sectors, but instead are consistent across the broad set of business activities that franchisors engage in.

Finally, we verified that our results were not driven by outlying observations. Since we already exclude outliers in terms of growth from our data (see the data section), we focused here on outliers defined in terms of chain size and age. We found that results were unaffected when we excluded observations from the top and bottom $5 \%$ of the franchised chain size distribution. However, excluding observations based on age had a substantial effect on our results. In particular, excluding young chains from our analyses affects results in important ways. Since analyses of mature chains are of interest for several reasons also from a theoretical perspective, we discuss these in detail below.

\section{IV(vi). Mature Chains}

Our long panel data set allows us to explore how results might differ when we focus on established franchised chains only. This is of interest because Jovanovic's [1982] learning model implies that the impact of firm age and size on firm dynamics should diminish with age, as mature firms have relatively precise expectations about their efficiency and no longer learn (or update) their type based much on market outcomes. Evans [1987a, b] also finds different data patterns for mature firms. Subsample analyses for

\footnotetext{
${ }^{48}$ These results are available upon request.

${ }^{49}$ Smaller sectors were excluded from these analyses due to small sample sizes. In addition, due to the small number of exits per sector we could not reliably estimate exit equations within sectors.
} 
TABLEV

\begin{tabular}{|c|c|c|c|c|}
\hline \multicolumn{5}{|c|}{$\begin{array}{c}\text { TABLEV } \\
\text { GROWTH - TOBIT AND LINEAR FIXED EFFECTS - YEARS IN FRANCHISING > } 7 \\
\text { (ALL SPECIFICATIONS CONTROL FOR CHAIN UNOBSERVED CORRELATED HETEROGENEITY) }\end{array}$} \\
\hline & \multicolumn{2}{|c|}{ Franchising Growth (FGrowth) } & \multicolumn{2}{|c|}{ Total Growth (TGrowth) } \\
\hline & Tobit $^{\mathrm{a}}$ & $\begin{array}{l}\text { Linear Fixed } \\
\text { Effects Model }\end{array}$ & Tobit $^{\mathrm{a}}$ & $\begin{array}{l}\text { Linear Fixed } \\
\text { Effects Model }\end{array}$ \\
\hline $\mathrm{Age}^{\mathrm{b}}$ & $\begin{array}{c}-2.77^{* * *} \\
(0.27)\end{array}$ & $\begin{array}{c}-2.01^{* * *} \\
(0.22)\end{array}$ & $\begin{array}{c}-1.41^{* * *} \\
(0.19)\end{array}$ & $\begin{array}{c}-1.09^{* * *} \\
(0.16)\end{array}$ \\
\hline Age Squared & $\begin{array}{c}0.03^{* * *} \\
(0.005)\end{array}$ & $\begin{array}{c}0.02^{* * *} \\
(0.004)\end{array}$ & $\begin{array}{c}0.01^{* * *} \\
(0.003)\end{array}$ & $\begin{array}{c}0.01^{* * *} \\
(0.002)\end{array}$ \\
\hline $\operatorname{Size}^{\mathrm{b}}(10)$ & $\begin{array}{l}-0.11^{* * *} \\
(0.02)\end{array}$ & $\begin{array}{c}-0.11^{* * *} \\
(0.02)\end{array}$ & $\begin{array}{l}-0.13^{* * *} \\
(0.02)\end{array}$ & $\begin{array}{l}-0.13^{* * *} \\
(0.02)\end{array}$ \\
\hline Size Squared (100) & $\begin{array}{r}0.00003^{*} \\
(0.00002)\end{array}$ & $\begin{array}{l}0.00003^{* *} \\
(0.0001)\end{array}$ & $\begin{array}{l}0.00002^{* * *} \\
(0.00001)\end{array}$ & $\begin{array}{l}0.00002^{* * *} \\
(0.00001)\end{array}$ \\
\hline Age $*$ Size $(10)$ & $\begin{array}{c}0.001 \\
(0.001)\end{array}$ & $\begin{array}{l}0.001^{*} \\
(0.0006)\end{array}$ & $\begin{array}{l}0.0014^{* *} \\
(0.0006)\end{array}$ & $\begin{array}{l}0.0014^{* * *} \\
(0.0004)\end{array}$ \\
\hline Bus. Experience & $\begin{array}{c}0.05 \\
(0.03)\end{array}$ & & & \\
\hline Percent Co-own & $\begin{array}{l}0.60^{* * *} \\
(0.06)\end{array}$ & $\begin{array}{l}0.61^{* * *} \\
(0.05)\end{array}$ & $\begin{array}{c}-0.01 \\
(0.05)\end{array}$ & $\begin{array}{c}-0.01 \\
(0.04)\end{array}$ \\
\hline Capital Required & $\begin{array}{c}-0.01 \\
(0.13)\end{array}$ & $\begin{array}{c}-0.03 \\
(0.11)\end{array}$ & $\begin{array}{r}-0.001 \\
(0.10)\end{array}$ & $\begin{array}{c}-0.01 \\
(0.08)\end{array}$ \\
\hline Franchise Fee & $\begin{array}{c}0.85 \\
(6.27)\end{array}$ & $\begin{array}{c}0.95 \\
(5.09)\end{array}$ & $\begin{array}{c}-0.94 \\
(4.91)\end{array}$ & $\begin{array}{c}-0.97 \\
(3.97)\end{array}$ \\
\hline Advertising Fee & $\begin{array}{c}0.46 \\
(0.46)\end{array}$ & $\begin{array}{c}0.55 \\
(0.37)\end{array}$ & $\begin{array}{c}0.54 \\
(0.36)\end{array}$ & $\begin{array}{r}0.55^{*} \\
(0.29)\end{array}$ \\
\hline Royalty Rate & $\begin{array}{c}0.58 \\
(0.40)\end{array}$ & $\begin{array}{c}0.59^{*} \\
(0.33)\end{array}$ & $\begin{array}{c}0.45 \\
(0.32)\end{array}$ & $\begin{array}{c}0.46^{*} \\
(0.26)\end{array}$ \\
\hline Ongoing Fixed Fee & $\begin{array}{c}0.28 \\
(3.00)\end{array}$ & $\begin{array}{c}0.43 \\
(2.42)\end{array}$ & $\begin{array}{c}2.30 \\
(2.42)\end{array}$ & $\begin{array}{c}2.26 \\
(1.95)\end{array}$ \\
\hline Canadian & $\begin{array}{l}-7.13 \\
(31.71)\end{array}$ & & $\begin{array}{r}-14.31 \\
(24.72)\end{array}$ & \\
\hline Constant & $\begin{array}{l}-5.10 \\
(32.07)\end{array}$ & $\begin{array}{l}20.17^{* * *} \\
(3.44)\end{array}$ & $\begin{array}{l}16.3 \\
(24.98)\end{array}$ & $\begin{array}{l}24.42^{* * *} \\
(3.09)\end{array}$ \\
\hline $\begin{array}{l}\text { Observations } \\
\# \text { of Chains } \\
\# \text { of Exits } \\
\mathrm{R}^{2} \\
\text { Log-likelihood } \\
\text { sigma_e }\end{array}$ & $\begin{array}{l}7998 \\
1640 \\
272 \\
0.01 \\
-37958 \\
31.08 \\
(0.25)\end{array}$ & $\begin{array}{l}7998 \\
1640 \\
272 \\
0.07\end{array}$ & $\begin{array}{c}7794 \\
1560 \\
64 \\
0.01 \\
-35728 \\
24.22 \\
(0.20)\end{array}$ & $\begin{array}{l}7794 \\
1560 \\
64 \\
0.05\end{array}$ \\
\hline
\end{tabular}

Notes: See Table III.

mature chains are of interest also because in the franchising literature, Lafontaine and Shaw [2005] have shown that it takes about seven to eight years for franchised chains to achieve a stable mix of company and franchised outlets, one that they tend to maintain from that point on. Thus franchisors' business practices are expected to be more stable among mature chains. Finally, Pakes and Ericson [1998] find that by age 8, unlike in manufacturing, the size distribution of firms in the retail sector is very close to its limit size distribution, suggesting again that retail firms of this age and above have achieved some degree of stability in the way they do business.

Table V reproduces the growth regressions in Table III for the subsample of franchised chains with at least 8 years of franchising experience. We find 
that chain age and size still have a negative effect on chain growth in this subsample. However, except for the effect of chain size in the franchising growth equation (FGrowth), the magnitude of the effects is much smaller than in the overall sample (Table III). Still, we find strong evidence of convergence in size among mature chains, just as in our overall sample.

Though not shown in the tables, we further analyzed the effect of age, size and other chain characteristics on growth using several other subsamples of mature franchised chains. We found that the age effect on chain growth, however defined, disappears only when the chains have been franchising or in business for 30 years or more. The negative effect of size on growth, moreover, remained even for the subsample of chains with more than 30 years in franchising. Evans [1987a, b] found similar results.

We conclude that chains converge in size to some chain-specific levels. In other words, chain size is bounded, contrary to the implications of Jovanovic and Rob [1987] and results obtained by Geroski et al. [2003]. However, Geroski et al.'s sample of very large and long-lasting manufacturing firms in Britain consists of mostly multi-product firms, rather than the singleproduct entities emphasized in the theory. In this vein, Dunne et al. [1989] find that firm growth falls with size and age only among single-plant firms, while among multi-plant firms the opposite is true. Assuming that multiplant firms are more likely to also be multi-product, their results are consistent with ours and Geroski's. And indeed models that consider the multi-product nature of firms yield different predictions, implying in particular that such firms may or may not be bounded in size (to our knowledge only the models by Klepper and Thompson [2006] and by Nocke and Yeaple [2006] clearly imply limits to 'overall' firm size). We believe that our result that individual chains converge in size arises clearly in our data exactly because of the single-product nature of franchised chains. We conclude that at the intensive margin - i.e., how much of a single product a firm produces - there are indeed limits to size and growth.

In Table VI, we show results for exit from franchising (FExit) for the sample of established franchised chains. Unfortunately, the small number of total chain exits does not allow us to reproduce the TExit analyses for mature chains. Also, we must replace the headquarters state dummy variables by a single regulation state dummy variable as we do not have a sufficient number of exits to use the full set of headquarters state variables. Controlling for chain fixed effects, the results show that neither size nor age $(\ln (p)$ is insignificant) have a significant impact on exit rates. This does not mean that large (older) chains do not exit, but rather that ceteris paribus, the probability of exit is unrelated to their size (age).

These findings are consistent with Jovanovic [1982] and similar learningtype models of industry dynamics. The reduced role of early learning processes for mature chains is further supported by the insignificance of the Business Experience variable in Tables V and VI (compare to Tables III, IV). 
TABLEVI

Exit From Franchising, - Weibull and COX — Years In Franchising $>7$ (ALL SPECIFICATIONS CONTROL FOR CHAIN UNOBSERVED CORRELATED HETEROGENEITY)

\begin{tabular}{lcc}
\hline & \multicolumn{2}{c}{ FExit: Exit from Franchising } \\
\cline { 2 - 3 } & Weibull $^{\mathrm{a}}$ & Cox $^{\mathrm{a}}$ \\
\hline Size $^{\mathrm{b}}(10)$ & 0.98 & 0.98 \\
& $(0.02)$ & $(0.02)$ \\
Size Squared (100) & 1.00 & 1.00 \\
& $(7.8 \mathrm{E}-06)$ & $(7.7 \mathrm{E}-06)$ \\
Bus. Experience & 0.99 & 0.99 \\
Percent Co-own & $(0.01)$ & $(0.01)$ \\
Capital Required & 1.00 & 1.00 \\
Franchise Fee & $0.01)$ & $(0.01)$ \\
& $1.12^{* * *}$ & $1.14^{* * *}$ \\
Advertising Fee & $(0.04)$ & $(0.04)$ \\
& $6.97^{* *}$ & $8.98^{* *}$ \\
Royalty Rate & $(6.15)$ & $(8.42)$ \\
Ongoing Fixed Fee & 0.98 & 0.98 \\
& $(0.06)$ & $(0.06)$ \\
Canadian & 0.97 & 0.96 \\
& $(0.04)$ & $(0.04)$ \\
Regulation State & $2.55^{* * *}$ & $2.81^{* * *}$ \\
& $(0.88)$ & $(1.12)$ \\
& $0.63^{*}$ & $0.65^{*}$ \\
Observations & $(0.15)$ & $(0.15)$ \\
\# of Chains & 1.15 & 1.16 \\
\# of Exits & $(0.16)$ & $(0.16)$ \\
ln $(p)$ & 7998 & 7998 \\
Log-likelihood & 1640 & 1640 \\
\hline
\end{tabular}

${ }^{\mathrm{a}} \mathrm{We}$ control for chain-level unobserved correlated heterogeneity (i.e. chain fixed effects) as discussed in Wooldridge [1995, 2002] - see Sections IV(ii)-IV(iii).

${ }^{\mathrm{b}}$ Size refers to franchised outlets.

Exponentiated coefficients reported. Robust standard errors calculated by the Delta method and adjusted for heteroscedasticity and chain-level clusters, in parentheses. Levels of significance assessed based on original coefficients and standard errors (see text). Significant at: ${ }^{*} 10 \% ;{ }^{* *} 5 \% ;{ }^{* * *} 1 \%$. All regressions contain sector and survey year dummy variables.

We also find that the proportion of company owned outlets no longer has an effect on exit rates, supporting the earlier arguments that mature chains had already found the right balance between the numbers of franchised and company owned outlets. Contract terms, on the other hand, continue to play a role similar to that found in our overall sample. The effects are even starker, with franchise fees and capital required increasing the likelihood that chains exit franchising, but having no significant effect on their growth, while higher royalty rates and advertising fees have a significant positive effect on the growth rates of mature chains. Thus a strong financial position 
for the franchisor, generated from ongoing fees based on outlets' sales, seems to ensure the growth of more mature chains.

The results above also imply that the strong positive effect of size on chain exit in Table IV must be driven by the young chains in our data, which, as mentioned in Section III(ii), represent more than $50 \%$ of our sample. In other words, it is young chains that have a tendency to make 'mistakes,' or to rely on over-optimistic assessments regarding their likelihood of success in the market, and grow too big early on. These chains then find that they have overstretched their resources or that the demand for their product is not as high as they anticipated, with the ultimate result being that they exit franchising or fail. ${ }^{50}$

\section{CONCLUSION}

In this paper, we have examined whether the age and size of franchised retail and service chains have the same effect on chain survival and growth as has been found in the empirical literature to date, most of which has focused on manufacturing firms/plants. We have also analyzed how contracting terms and chain characteristics may affect chains' survival and growth, and whether the stylized facts concerning age and size effects might be driven by such characteristics, as suggested, e.g., by Klepper and Thompson [2006].

We found a negative impact of age and size on chain growth, and a positive impact of age on chain survival, as in the previous literature, even after controlling for chain unobserved correlated heterogeneity (or chain fixed effects). Thus firms' learning process about their 'unobserved efficiency' or 'type' - as posited by Jovanovic-type models - is not the only reason for age and size to affect firm growth or exit. Moreover, the robustness of these results to whether or not we include the contract variables and other chain characteristics implies that these other variables also are not driving the age and size effects.

In addition, we found that controlling for chain fixed effects is crucial in these analyses, as it reverses the impact of size on chain survival. Specifically, being larger increases the likelihood of chain exit rather than decreasing it. For mature chains, however, we find no evidence that age or size affects exit rates. We conclude that young chains make 'mistakes' - or over-optimistic assessments about their odds of success in the market by overestimating demand or their resources - and subsequently, after a few periods of high growth, find that their 'efficiency/type' was not that high, and exit. We believe that the positive effect of size on exit may show up more clearly in our data on franchised chains because business concepts in the types of industries where one finds franchising often can be copied fairly easily. Yet

\footnotetext{
${ }^{50}$ According to InfoPress [1988] franchisors often project unrealistically high growth rates in their first few years.
} 
the trade press suggests that franchisors attribute much value to their brand/ franchise concepts. Moreover, given the contractual relationship upon which franchising relies, franchisees, not the franchisor, bear most of the cost of outlet failures. ${ }^{51}$ Thus, if the product concept or outlets turns out to be unsuccessful, instead of downsizing/shrinking - as Jovanovic-type models would predict, and as implied by the 'shadow of death effect' observed in manufacturing, e.g., Griliches and Regev [1995] - franchisors can exit while being relatively large, as the recent example of Bennigan's documents. ${ }^{52}$ Similar issues of overconfidence, and principal-agent problems between creditors and equity holders, or between managers and shareholders, have been documented in the finance and entrepreneurship literature, e.g., Ritter [1991] or Goel and Thakor [2008], but have not been explored in the literature on industry and firm dynamics.

Our results also provide strong evidence that chains converge in size towards chain-specific sizes. Rather than being the consequence of the type of cost efficiency parameter emphasized in models such as Jovanovic's, however, in the type of industries where franchising occurs, the limit more likely arises from consumers' tastes for product diversity. In other words, some chains, like McDonald's and Subway, can grow very large but, in the end, customers still value having different alternative products available to them. Large franchising firms can address this desire for variety by establishing several franchised chains offering different types of product. Some franchising companies have pursued growth in this way, including, for example, Yum! Brands, owner of Pizza Hut, Taco Bell, KFC and others. In our data, however, these different chains appear as separate entities whose size, per our results, is again bounded.

Results in Geroski et al. [2003] and other studies of large manufacturing firms (see Sutton [1997], Caves [1998] and Audretsch et al. [2004] for surveys), in contrast, suggest an absence of size-convergence in manufacturing. But large manufacturing firms are likely to be highly diversified - or multi-product - entities that have introduced and abandoned numerous products over the years. Mitchell [2000], Klepper and Thompson [2006], Bernard, Redding and Schott [2006, 2010] and Nocke and Yeaple [2006] have all proposed models of firm dynamics where firms engage in more than

\footnotetext{
${ }^{51}$ For example, in the hotel industry The Economist [2009] notes: 'However, the brunt of recession will be borne by the hotels' owners [franchisees] rather than chains that manage and franchise them. Simon Mezzanotte of Société Générale, a bank, explains that if RevPar (revenue per available room) falls $1 \%$ at a hotel, its owner [franchisee] typically suffers a $5 \%$ profits fall.' But the management and franchise fees [collected by franchisors] fall only by $3 \%$ and $1 \%$ respectively. '[Thus] many hotel owners [franchisees], having taken most of the risk, will collapse into bankruptcy during the recession.'

${ }^{52}$ Business Week. 'After a Franchisor Files for Bankruptcy'. August 4, 2008. Hotel franchisors use similar practices - if a property/franchisee no longer delivers on the brand promise or may in fact hurt the overall image, the hotel can be converted into an independent property without franchisor's support (HNN Hotelnewsnow.com [Feb. 5, 2009]).
} 
one activity. While these models imply a limit to firm scope (i.e., the number of different products they offer), this literature has not fully explored differences in intensive (how much of each product is produced) vs. extensive (how many products are offered) margins for firm growth. We leave the very interesting question of how firm scope and experience with various products might affect chain and firm size and growth for future work. Our analyses and results on the effect of product-level experience - age and size - on product-level growth and survival, however, show that there are indeed limits to size on the intensive margin. In that sense, our results underscore the importance of recognizing the existence of these different margins for firm growth in empirical work on firm dynamics.

More generally, we view our results as highlighting the need for theoretical models, as well as future empirical work, on firm and industry dynamics to better account for organizational and institutional features of industry. In our setting, for example, contracting practices clearly matter for both growth and exit, and that even for mature chains. Similarly, incorporating into the theory the possibility of different ownership structures, and the related capacity of firms to have others - here franchisees - bear much of the exit costs, could help explain cross-industry differences in entry and exit rates. Finally, from a public policy perspective, our findings also imply a role for education, in this case of franchisees, as to the potential risks of failure, and how such risks may be affected by a chain's reliance on franchising.

\section{APPENDIX}

Our data set is an unbalanced panel. Table AI lists the 23 sectors in which these firms operate, and descriptive statistics for each sector.

\section{Sample Definition}

From an original 22,299 observations, we excluded 83 because they reported a royalty rate above $30 \%$, leading us to believe that these were not royalties based on sales. This gave us our sample of 22,216 observations across 5,044 chains. We then lost 6,681 observations for FGrowth and 7,712 for TGrowth because either the growth rate was missing (we did not have subsequent data to calculate the growth rate), or we were missing data for various regressors in different years. Note that we ignore single year gaps in our data, calculating growth as ((outlets at time $t+2)-($ outlets at time $t)) /$ outlets at time $t$ in these cases. Almost all these gaps arise because of the missing data for 1999. Also, there are observations where we have zero franchised outlets at time $t$, which presents a problem in calculating franchising (FGrowth). (This is not an issue for total growth (TGrowth) since there is always at least one outlet, franchised or not, in a chain in our data). If there were still no franchised outlets the next year and the franchisor did not officially exit, we set FGrowth equal to zero in these cases. If a franchisor did officially exit we set FGrowth equal to $-100 \%$. If there were franchised outlets the next year, to avoid infinite growth rates, we replaced franchised outlets at time $t$ by 1 and calculated the growth rates as usual. 


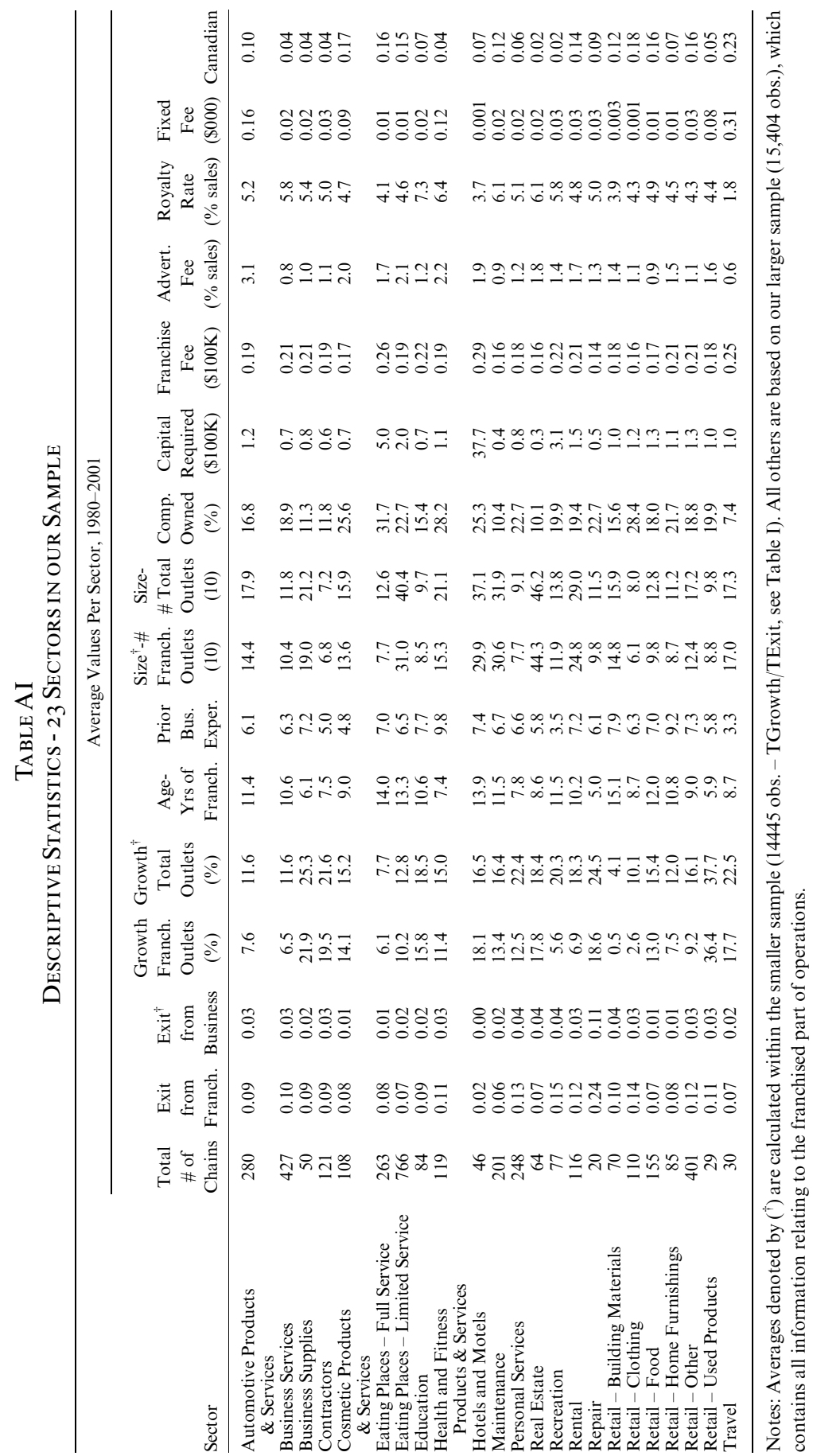




\section{REFERENCES}

Agarwal, R. and Gort, M., 1996, 'The Evolution of Markets and Entry, Exit and Survival of Firms,' The Review of Economics and Statistics, 78, pp. 489-498.

Agarwal, R. and Gort, M., 2002, 'Firm and Product Life Cycles and Firm Survival,' The American Economic Review, 92, pp. 184-190.

Audretsch, D. B.; Klomp, L.; Santarelli, E. and Thurik, A. R., 2004, 'Gibrat's Law: Are the Services Different?,' Review of Industrial Organization, 24, pp. 301-324.

Azoulay, P. and Shane, S., 2001, 'Entrepreneurs, Contracts and the Failure of Young Firms,' Management Science, 47, pp. 337-358.

Basker, E. and Pham, H. V., 2007, 'Wal-Mart as Catalyst to U.S.-China Trade,' University of Missouri working paper, Columbia, Missouri, U.S.A.

Bernard, A. B.; Redding, S. J. and Schott, P. K., 2006, 'Multi-Product Firms and Product Switching', NBER working paper no. 12293, (NBER, Cambridge, Massachusetts, U.S.A.).

Bernard, A. B.; Redding, S. J. and Schott, P. K., 2010, 'Multiple-Product Firms and Product Switching,' The American Economic Review, 100, pp. 629-685.

Blair, R. D. and Lafontaine, F., 2005, The Economics of Franchising (Cambridge University Press, New York, U.S.A.).

Bloom, N.; Sadun, R. and Van Reenen, J., 2007, 'Americans do IT Better: U.S. Multinationals and the Productivity Miracle,' CEP discussion paper no.788, London School of Economics, London, England.

Bond, R., Various years, Bond's Franchise Guide (Source Book Publications, Oakland, California, U.S.A.).

Bond, R., Various Years, The Source Book of Franchise Opportunities (Richard D. Irwin Publishing, Burr Ridge, Illinois, U.S.A.).

Bradach, J. L., 1998, Franchise Organizations (Harvard Business School Press, Boston, Massachusetts, U.S.A.).

Bureau of Labor Statistics, 'Summary Table B., Employment, Hours, and Earnings of Employees on Nonfarm Payrolls, Seasonally Adjusted (ftp://ftp.bls.gov/pub/suppl/ empsit.cessum.txt)

Business Week, 2008 (August 4), 'After a Franchisor Files for Bankruptcy.'

Cabral, L. M. B. and Mata, J., 2003, 'On the Evolution of the Firm Size Distribution: Facts and Theory,' The American Economic Review, 93, pp. 1075-1090.

Caves, R. E., 1998, 'Industrial Organization and New Findings on the Turnover and Mobility of Firms,' Journal of Economic Literature, 36, pp. 1947-1982.

Clementi, G. L. and Hopenhayn, H. A., 2006, 'A Theory of Financing Constraints and Firm Dynamics,' The Quarterly Journal of Economics, 121, pp. 229-265.

Cooley, T. F. and Quadrini, V., 2001, 'Financial Markets and Firm Dynamics,' The American Economic Review, 91, pp. 1286-1310.

Cox, D. R., 1972, 'Regression Models and Life Tables' (with discussion), Journal of Royal Statistical Society, Series B (34), pp. 187-220.

Disney, R.; Haskel, J. and Heden, Y., 2003, 'Entry, Exit and Establishment Survival in U.K. Manufacturing,' Journal of Industrial Economics, 51, pp. 91-112.

Dunne, T.; Roberts, M. J. and Samuelson, L., 1988, 'Patterns of Firm Entry and Exit in U.S. Manufacturing Industries,' RAND Journal of Economics, 19, pp. 495-515.

Dunne, T.; Roberts, M. J. and Samuelson, L., 1989, 'The Growth and Failure of U.S. Manufacturing Plants,' The Quarterly Journal of Economics, 104, pp. 671-698.

Entrepreneur, 'Franchise 500,' various years.

Ericson, R. and Pakes, A., 1995, 'Markov Perfect Industry Dynamics: A Framework for Empirical Work,' Review of Economic Studies, 62, pp. 53-82. 
Evans, D. S., 1987a, 'Test of Alternative Theories of Firm Growth,' Journal of Political Economy, 95, pp. 657-674.

Evans, D. S., 1987b, 'The Relationship between Firm Growth, Size and Age: Estimates for 100 Manufacturing Industries,' The Journal of Industrial Economics, 35, pp. 567-581.

Franchise Annual, various years. (Info Franchise News, Inc., Lewiston, New York, U.S.A.)

Foster, L.; Haltiwanger, J. and Krizan, C. J., 2006, 'Market Selection, Reallocation and Restructuring in the U.S. Retail Trade Sector in the 1990s,' Review of Economics and Statistics, 88, pp. 748-758.

Frazer, L., 2001, 'Why Franchisors Discontinue Franchising but Continue Operating,' International Small Business Journal, 19, pp. 29-38.

Geroski, P. A.; Lazarova, S.; Urga, G. and Walters, C. F., 2003, 'Are Differences in Firm Size Transitory or Permanent?,' Journal of Applied Econometrics, 18, pp. 47-59.

Goel, A. M. and Thakor, A. V., 2008, 'Overconfidence, CEO Selection and Corporate Governance,' Journal of Finance, 63, pp. 2737-2784.

Gort, M., 1962, Diversification and Integration in American Industry (Princeton Univ. Press, Princeton, New Jersey, U.S.A.).

Griliches, Z. and Regev, H., 1995, 'Firm Productivity in Israeli Industry 1979-1988,' Journal of Econometrics, 65, pp. 175-203.

Hall, B. H., 1987, 'The Relationship between Firms' Size and Firm Growth in the U.S. Manufacturing Sector,' Journal of Industrial Economics, 35, pp. 583-606.

Hopenhayn, H. A., 1992, 'Entry, Exit and Firm Dynamics in Long Run Equilibrium,' Econometrica, 60, pp. 1127-1150.

Hosmer Jr., D. W. and Lemeshow, S., 1999, Applied Survival Analysis: Regression Modeling of Time to Event Data (John Wiley \& Sons, Inc., New York, U.S.A.).

HNN Hotelnewsnow.com., 2009 (January 20), 'Accor NA Opens 57 Hotels in 2008.

HNN Hotelnewsnow.com., 2009 (Februrary 5), '2008 Experiences Uptick in Conversions.'

InfoPress, Inc, 1988, 'Letter from Harold Krieger and Michael Seid,' Info Franchise Newsletter, 12, pp. 2-3.

Jarmin, R. S.; Klimek, S. D. and Miranda, J., 2004, 'Firm Entry and Exit in the U.S. Retail Sector,' pp. 1977-1997, CEPR working paper no. 04-17, available at http:// ideas.repec.org/e/pja54.html

Jovanovic, B., 1982, 'Selection and the Evolution of Industry,' Econometrica, 50, pp. 649-670.

Jovanovic, B. and Rob, R., 1987, 'Demand-Driven Innovation and Spatial Competition over Time,' Review of Economic Studies, 54, pp. 63-72.

Kaufmann, P. J., 1987, Pizza Hut, Inc., HBS case 9-588-011, available at http:// cb.hbsp.harvard.edu/cb/search/9-588-011?Ntk $=$ HEmainSearch $\& N=0$

Kirby, D. A. and Watson, A., 1999, 'Franchising as a Strategy for Growth: The Case of the Construction Industry,' in Thirteenth Annual Proceedings of the International Society of Franchising, Stanworth J. and D. Purdy (eds.), see http://www.huizinga.nova.edu/ExecEd/ISOF/ISOFGetPapers.cfm

Klepper, S. and Thompson, P., 2006, 'Submarkets and the Evolution of Market Structure,' RAND Journal of Economics, 37, pp. 861-886.

Kosová, R.; Lafontaine, F. and Zhao, B., 2009, 'Scale, Scope and Takeovers: Evidence from Franchising,' working paper, University of Michigan Ross School of Business, Ann Arbor, Michigan, U.S.A.

Lafontaine, F., 1992, 'Agency Theory and Franchising: Some Empirical Results,' RAND Journal of Economics, 23, pp. 263-283.

Lafontaine, F. and Shaw, K. L., 1998, 'Franchising Growth and Franchisor Entry and Exit in the U.S. Market: Myth and Reality,' Journal of Business Venturing, 13, pp. 95-112. 
Lafontaine, F. and Shaw, K. L., 1999, 'The Dynamics of Franchise Contracting: Evidence from Panel Data,' Journal of Political Economy, 107, pp. 1041-1080.

Lafontaine, F. and Shaw, K. L., 2005, 'Targetting Managerial Control: Evidence from Franchising,' RAND Journal of Economics, 36, pp. 131-150.

Lafontaine, F. and Sivadasan, J., 2009, 'The Microeconomic Implications of Input Market Regulations: Cross-Country Evidence from within the Firm,' American Economic Journal - Applied, 1, pp. 88-127.

Lafontaine, F. and Slade, M. E., 2007, 'Vertical Integration and Firm Boundaries: The Evidence,' Journal of Economic Literature, 45, pp. 629-685.

Mitchell, M. F., 2000, 'The Scope and Organization of Production: Firm Dynamics over the Learning Curve,' RAND Journal of Economics, 31, pp. 180-205.

Mundlak, Y., 1978, 'On the Pooling of Time Series and Cross Section Data,' Econometrica, 46, pp. 69-85.

Nocke, V. and Yeaple, S., 2006, 'Globalization and Endogeneous Scope,' working paper, University of Pennsylvania, Philadelphia, Pennsylvania, U.S.A.

O’Mahony, M. and van Ark, B., 2003, EU Productivity and Competitiveness: An Industry Perspective, European Commission, Luxembourg.

Pakes, A. and Ericson, R., 1998, 'Empirical Implications of Alternative Models of Firm Dynamics,' Journal of Economic Theory, 79, pp. 1-45.

Petrunia, R., 2007, 'Impact of Initial Debt on the Long-Term Employment Growth of New Firms,' Canadian Journal of Economics, 40, pp. 861-880.

Petrunia, R., 2008, 'Does Gibrat's Law Hold? Evidence from Canadian Retail and Manufacturing Firms,' Small Business Economics, 30, pp. 201-214.

PricewaterhouseCoopers, 2008, Economic Impact of Franchised Businesses (International Franchise Association, Washington, D.C., U.S.A.).

Ritter, J. R., 1991, 'The Long-Run Performance of Initial Public Offerings,' Journal of Finance, 46, pp. 3-27.

Shane, S. A., 1996, 'Hybrid Organizational Arrangements and their Implications for Firm Growth and Survival: A Study of New Franchisors,' Academy of Management Journal, 39, pp. 216-234.

Stanworth, J.; Purdy, D.; Price, S. and Zafiris, N., 1998, 'Franchise Versus Conventional Small Business Failure Rates in the U.S. and U.K.: More Similarities than Differences,' International Small Business Journal, 16, pp. 56-69.

Sutton, J., 1997, 'Gibrat's Legacy,' Journal of Economic Literature, 35, pp. 40-59.

Sutton, J., 1998, Technology and Market Structure (MIT Press, Cambridge, Massachusetts, U.S.A.).

Troske, K. R., 1996, 'The Dynamic Adjustment Process of Firm Entry and Exit in Manufacturing, and Finance, Insurance and Real Estate,' Journal of Law and Economics, 39, pp. 705-735.

Trutko, J.; Trutko, J. and Kostecka, A., 1993, Franchising's Growing Role in the U.S. Economy, 1975-2000 (U.S. Department of Commerce, National Technical Information Service, Springfield, Virginia, U.S.A.).

The Economist, 2009, (February 19), 'Outsourcing as You Sleep.'

U.S. Department of Commerce (USDOC), 1988, Franchising in the Economy (Washington, D.C., U.S.A.).

Wooldridge, J. M., 1995, 'Selection Corrections for Panel Data Models under Conditional Mean Independence Assumptions,' Journal of Econometrics, 68, pp. 115-132.

Wooldridge, J. M., 2002, Econometric Analysis of Cross Section and Panel Data (MIT Press, Cambridge, Massachusetts, U.S.A.). 